\title{
FLORA DE GRÃO-MOGOL, MINAS GERAIS: MELASTOMATACEAE ${ }^{1}$
}

\author{
ANGELA BORGES MARTINS*, RENATO GOLDENBERG** \& JOÃO SEMIR* \\ *Departamento de Biologia Vegetal, Instituto de Biologia, Universidade Estadual de Campinas, \\ Caixa postal 6109, 13081-970 - Campinas, SP, Brasil. \\ ${ }^{*}$ Departamento de Botânica, Setor de Ciências Biológicas, Universidade Federal do Paraná, \\ Caixa postal 19041, 81531-970 - Curitiba, PR, Brasil.
}

BAUMGRATZ J.F.A., SOUZA, M.L.D.R., MARTINS, A.B., LUGHADHA, E.N. \& WOODGYER, E.M. 1995. Melastomataceae. In B.L. Stannard (ed.) Flora of the Pico das Almas, Chapada Diamantina, Bahia, Brazil. Royal Botanical Gardens. Kew, p. 433-483.

COGNIAUX, A. 1883-1885. Melastomaceae. In C.F.P. Martius \& A.G. Eichler (eds.) Flora brasiliensis.Frid.Fleischer. Leipzig, vol. 14, pars 3, p. 1-510, tab. 1-108.

COGNIAUX, A. 1886-1888. Melastomaceae. In C.F.P. Martius, A.G. Eichler \& I. Urban (eds.) Flora brasiliensis. Frid. Fleischer. Leipzig, vol. 14, pars 4, p. 1-655, tab. 1-130.

COGNIAUX, A. 1891. Melastomataceae. In A. De Candolle \& C. De Candolle (eds.) Monographiae Phanerogamarum. Masson. Paris, vol. 7: 1-1256.

DE CANDOLLE, A.P. 1828. Melastomaceae. In A.P. De Candolle (ed.) Prodromus Systematis Naturalis. Treutel et Würtz. Paris, vol. 3, p. 99-202.

FRITSCH P.W., ALMEDA F., RENNER, S.S., MARTINS, A.B., CRUZ, B.C. 2004. Phylogeny and circumscription of the near-endemic Brazilian tribe Microlicieae (Melastomataceae). Amer. J. Bot. 91(7): 1105-1114.

1. Folhas com vesícula (formicário) arredondada e inflada na base da lâmina

Tococa

1'. Folhas sem vesícula, às vezes com domácias entre as nervuras ou na base da lâmina.

2. Baga carnosa ou coriácea; estames normalmente em 2 séries iguais ou subiguais; cálice normalmente duplo, o externo com dentes inconspícuos. Flores pequenas e pouco vistosas.

3. Inflorescência lateral ou axilar

Clidemia

3'. Inflorescência terminal.

4. Pétalas com ápice agudo; conectivo normalmente pouco prolongado e inapendiculado Leandra

4'. Pétalas com ápice obtuso, arredondado a emarginado; conectivo às vezes prolongado com apêndices dorsais, ventrais ou ambos Miconia

2'. Cápsula, seca, deiscência longitudinal apical ou basal; estames em 2 séries desiguais, as vezes subiguais; cálice nunca duplo. Flores vistosas.

5. Sementes cocleadas.

6. Flores pentâmeras, ovário normalmente com tricomas no ápice Tibouchina

6'. Flores tetrâmeras.

7. Estames com conectivo não prolongado Marcetia

7'. Estames com conectivo prolongado.

8. Estames com tricomas glandulares no conectivo Macairea

8'. Estames glabros Comolia

5'. Sementes oblongas, ovóides, piramidais, cuneadas, anguladas até fusiformes, não cocleadas.

9. Anteras subuladas, não rostradas, sem apêndice, ou anteras oblongas, com apêndice dorsal.

10. Anteras em 2 séries iguais ; conectivo não prolongado e sem apêndices; pétalas bicolores amarelas e vermelhas Cambessedesia

\footnotetext{
${ }^{1}$ Trabalho realizado conforme o planejamento apresentado por Pirani et al. (2003). Bol. Bot. Univ. Sâo Paulo 21(1): 1-24.
} 
10'. Anteras em 2 séries desiguais; conectivo com apêndice dorsal; pétalas púrpuras, magenta a lavanda Merianthera

9'. Anteras oblongas, curta ou longamente rostradas; conectivo normalmente alargado na base; apêndice ventral.

11. Hipanto com coroa de tricomas setosos no ápice Chaetostoma

11'. Hipanto sem coroa de tricomas setosos no ápice.

12. Plantas herbáceas, flores 4-meras, ovário bilocular Siphanthera

12'. Plantas normalmente subarbustivas, arbustivas até arbóreas, flores 3-8-meras, ovário 3-8-locular, se bilocular, então plantas nunca herbáceas.

13. Flores 6-8 meras, às vezes 5-meras, cápsulas com deiscência basal Lavoisiera

13'. Flores 3-5 meras, cápsula com deiscência apical.

14. Estames com uma série fértil e outra constituida por estaminódios, às vezes com um estame da série fértil maior e bem destacado, de rostro muito longo Rhynchanthera

14'. Estames com as duas séries férteis de tamanhos desiguais.

15. Ovário normalmente 5-locular, inflorescência dicasial terminal Trembleya

15'. Ovário normalmente 3-locular, flores isoladas axilares com duas brácteas no pedicelo Microlicia

\section{Cambessedesia DC.}

MARTINS, A. B. 1995. Notas nomenclaturais e taxonômicas em Melastomataceae: combinações novas em Cambessedesia DC. e Marcetia DC. Acta bot.bras. 9(1): 147-149.

Subarbustos ou arbustos, geralmente com xilopódio bem desenvolvido. Ramos com indumento variado ou glabros, assim como ambas as faces das folhas, hipanto e cálice. Folhas pecioladas ou sésseis, opostas ou em braquiblastos formando pseudofascículos, membranáceas a coriáceas, margem inteira, serreada ou crenulada. Inflorescências em dicásios simples, compostos ou modificados, espiciformes ou tirsóideos, frequentemente folhosas, axilares e terminais. Flores 5-(-6)-meras. Hipanto oblongo a campanulado ou urceolado. Cálice persistente, lacínias triangulares a subcordadas. Pétalas bicolores, vermelhas no ápice e amarelas na base, algumas vezes totalmente amarelas ou vermelhas. Estames (5) 10 (12), isomorfos ou dimorfos, anteras linear-oblongas, retas ou encurvadas, conectivo espessado no dorso e eventualmente apendiculado na base. Ovário súpero ou semi-aderido à base do hipanto, 3-6 locular, ápice glabro ou piloso. Cápsula loculicida, envolvida pelo hipanto persistente, deiscente no ápice. Sementes numerosas, retas ou levemente encurvadas, superfície tuberculada a papilada.

1. Ramos cilíndricos a subcilíndricos com indumento não glandular; pétalas totalmente amarelas C. espora subsp. ilicifolia

1'. Ramos subcilíndricos a quadrangulares com indumento glandular ou glabros; pétalas bicolores, amarelas na base e vermelhas no ápice C. hilariana

1.1. Cambessedesia espora subsp. ilicifolia (Schrank et Mart. ex DC.) A.B. Martins, Acta bot. bras. 9: 148. 1995.

Subarbusto (30-)50(-100) cm alt. Caule e ramos cilíndricos ou subcilíndricos com pilosidade curta e densa. Folhas sésseis ou subsésseis, em braquiblastos folhosos; lâmina 3-5 mm compr., 3-5 mm larg. cartácea, cordiforme a oval lanceolada, cordada na base e aguda no ápice, margem geralmente denteada, glabra ou esparsamente pilosa, 3-5 nervuras acródromas basais. Inflorescências axilares e terminais, tirsóideas ou espiciformes. Bractéolas sésseis, ovais, glabras, com 2-2,5 mm compr., 1,5-1,8 mm larg. Flores 5-meras, subsésseis. Hipanto $5 \mathrm{~mm}$ compr., oblongo a ligeiramente urceolado, glabro ou esparsamente piloso; lacínias ca. $3 \mathrm{~mm}$ compr. Pétalas 5-7 mm compr., $3 \mathrm{~mm}$ de larg., elípticas ou oblongo-lanceoladas, acuminadas, totalmente amarelas. Es- tames subisomorfos, filetes glabros ou esparsamente pilosos, antessépalos: $6,5 \mathrm{~mm}$ compr., anteras $5 \mathrm{~mm}$ compr., antepétalos: 5,5 mm compr., anteras $4 \mathrm{~mm}$ compr. Ovário ca. $3 \mathrm{~mm}$ compr., ápice piloso, 3(-4)-locular. Cápsula 4-5 mm compr, globosa ou urceolada; sementes ca. 0,5 mm compr. (Fig. 1. A).

\section{Harley et al. CFCR 6447 (SPF, UEC).}

Encontrada com frequência em Minas Gerais, São Paulo e norte do Paraná, mais raramente no Distrito Federal e Goiás. Tem sido tradicionalmente separada de Cambessedesia espora subsp. espora, que ocorre principalmente em Goiás e Minas Gerais, pelos ramos subcilíndricos e pubérulos, em contraste com ramos quadrangulares e glabros apresentados pela subespécie típica. Os dois variantes morfológicos são portanto simpátricos em Minas Gerais e Goiás, onde eventu- 
almente ocorrem indivíduos intermediários, provavelmente híbridos naturais entre as duas formas, e que correspondem às variedades de Cambessedesia ilicifolia descritas por Cogniaux (1883). Estas variedades não são aceitas nesse trabalho. Floresce e frutifica ao longo de todo o ano. Em GrãoMogol foi coletada em campo rupestre.

\subsection{Cambessedesia hilariana (Kunth) DC., Prodr. 3: 111.} 1828.

Subarbusto (10-) 50 (-100) cm alt. Ramos subcilíndricos a quadrangulares, levemente piloso-glandulosos ou glabros. Folhas subsésseis em braquiblastos axilares folhosos; lâmina 0,2-3 cm compr., 0,1-0,5 cm larg., subcartácea, oval-lanceolada a linear, atenuada na base e aguda ou arredondada no ápice, margem inteira ou denteado-ciliada, glabra ou esparsamente pilosa em uma ou nas duas faces, 1-3(-5) nervuras acródromas basais. Inflorescências terminais e axilares em dicásios simples, compostos ou reduzidos. Bractéolas ovallanceoladas. Flores 5-meras, subsésseis. Hipanto 1,5-3 mm compr., glabro ou com tricomas glandulares. Pétalas 5,5-9 mm compr., 3-4 mm larg., amarelas na base e vermelhas no ápice, ovais. Estames dimorfos ou subisomorfos; antessépalos: filetes 5-7 mm compr., anteras 6-12 mm compr., encur- vadas, conectivo espessado no dorso; antepétalos: filetes 4-5 mm compr. e anteras 2-8 mm compr., quase retas. Ovário 3-locular. Cápsula 4-8 mm compr., globosa ou oblonga; sementes 0,3-0,5 mm compr. (Fig. 1. B-C).

Barreto et al. CFCR 12001 (SPF, UEC); Cordeiro et al. CFCR 859 (SPF, UEC); Furlan et al. CFCR 748 (SPF, UEC); Freire-Fierro et al. CFCR 12583 (SPF, UEC); Hatschbach 41284 (MBM, SPF); Kameyama et al. CFCR 859 (SPF, UEC); Mamede et al. CFCR 3515 (SPF, UEC); Mello-Silva CFCR 9648 (SPF, UEC); Semir et al. 50 (UEC); Silva et al. CFCR 12459 (SPF, UEC); Simão-Bianchini et al. CFCR 12918 (SPF, UEC).

Espécie bastante polimórfica amplamente distribuída desde o Piauí até o Paraná. Habita preferencialmente campos rupestres ao longo da Serra do Espinhaço, em Minas Gerais, e na Chapada Diamantina, na Bahia, estando também bem representada nas serras de Goiás. Muitos indivíduos crescem em campos cerrados. Floresce e frutifica praticamente o ano todo, com pico de floração de janeiro a abril. É a espécie à qual foi atribuído o maior número de variedades dentro do gênero, exatamente por ser a que apresenta maior amplitude no padrão de variação de suas características. Em Grão-Mogol foi coletada em solo arenoso, campo sujo e em afloramentos rochosos no campo rupestre.

\section{Chaetostoma DC.}

KOSCHNITZKE, C. \& MARTINS, A. B. 1999. New combinations and a new especies in the Brazilian genus Chaetostoma DC. (Microlicieae: Melastomataceae). Novon 9(2): 202-204.

KOSCHNITZKE, C. \& MARTINS, A. B. 2003. Proposal to conserve the name Chaetostoma pungens against Rhexia armata (Melastomataceae, Microlicieae). Taxon 52: 366-367.

KOSCHNITZKE, C. \& MARTINS, A. B. 2006. Revisão taxonômica de Chaetostoma DC. (Melastomataceae, Microlicieae). Archos. Mus. Nacional 64: 95-119.

Subarbustos eretos, cespitosos ou decumbentes. Ramos glabros. Entrenós revestidos por expansões foliares. Folhas imbricadas adpressas, eretas, sésseis, coriáceas, carenadas a subcarenadas, margem serrilhado-ciliada ou inteira, calosa, ápice quase sempre pungente, ambas as faces geralmente glabras, 1-7 nervuras subparalelas. Flores 5-meras, isoladas, terminais, uma por ramo, raramente 2-3, sésseis a subsésseis. Hipanto campanulado a oblongo- campanulado, glabro a esparsamente piloso, com coroa de tricomas longos ou curtos no ápice; lacínias persistentes, triangulares a subuladas. Pétalas púrpuras, magenta, amarelas ou brancas, raramente bicolores ou até tricolores. Estames 10, dimorfos; anteras amarelas, retas ou levemente encurvadas; conectivo curto ou prolongado. Ovário súpero ou semi-aderido à base do hipanto, 3-5 locular. Cápsula loculicida, envolvida pelo hipanto persistente, deiscente no ápice. Sementes reniformes, numerosas, testa reticulada.

2.1. Chaetostoma armatum (Spreng.) Cogn. in Mart., Fl. bras. 14(3): 31. 1883.

Rhexia armata Spreng., Syst. Veget. 2: 308. 1825.

Chaetostoma pungens DC., Prodr. 3: 112. 1828.

Subarbusto 20-50 cm alt. Ramos glabros. Folhas sésseis, lâmina 0,4-1 cm compr., 0,1-0,2 cm larg., triangular-lanceolada a subulada, ápice acuminado, pungente, margem serrilhada ou serrilhado-ciliada, face adaxial com tricomas glandulares esparsos, 3-7 nervuras. Flores isoladas, subsésseis.
Hipanto 4-6 mm compr.; glabro, tricomas da coroa 0,5-3 mm compr., pungentes; cálice persistente com lacínias 3,5-9 mm compr. Pétalas 8-12 mm compr., 5-8 mm larg., magenta, obovadas. Estames dimorfos, antessépalos: filete 4-5,5 mm compr., antera 4,5-7 mm compr., subulada, amarela, conectivo prolongado ca. $1 \mathrm{~mm}$, curtamente apendiculado; antepétalos: filete 3,5-5 mm compr., antera 3-5 mm compr., subulada, conectivo prolongado ca. $0,5 \mathrm{~mm}$, inapendiculado. Ovário súpero, 3-locular. Cápsula 3,5-7 mm compr., oblonga. Sementes ca. 0,5 mm compr. (Fig. 1. D-F). 

UEC).

Markgraf et al. 3436 (UEC); Mello-Silva et al. CFCR 9904 (SPF,

Espécie bastante variável morfologicamente e razoavelmente bem distribuída na região sudeste do Brasil onde é praticamente restrita, ocorrendo desde o sul da Bahia até o norte do Paraná. Ocorre em maior abundância nos cerrados e campos rupestres da Serra do Espinhaço e nas serras do sudoeste de Minas Gerais, e mais raramente em áreas campes- tres no sul de São Paulo e norte do Paraná. Em Grão Mogol foi encontrada em campo pedregoso. Coletada com flores em maio e novembro.

A recente proposta (Koschnitzke \& Martins 2003) de conservar o nome $C$. pungens, até agora atribuído a esta espécie em toda a literatura especializada e em etiquetas de herbário, não foi aceita. Portanto, o epíteto correto para este táxon é o que está sendo aqui adotado, por ser o mais antigo.

\section{Clidemia D. Don}

GOLDENBERG, R., SOUZA, C.M.F. \& DEQUECH, H.B. 2005. Clidemia, Ossaea e Pleiochiton (Melastomataceae) no estado do Paraná, Brasil. Hoehnea 32(3): 453-466.

Arbustos até $3 \mathrm{~m}$ alt., eretos, escandentes ou lianas, geralmente pilosos com indumento variável. Ramos cilíndricos. Folhas pecioladas, membranáceas, geralmente anisófilas, nervuras 3-7, acródromas basais ou supra-basais. Inflorescências cimosas axilares ou pseudolaterais, brácteas semelhantes às folhas, bractéolas geralmente diminutas. Flores 4-5(8)-meras, subsésseis; hipanto oblongo a urceolado, cálice duplo. Pétalas brancas a róseas, obovadas ou oblongas, arredondadas no ápice. Estames 8-10 isomorfos ou levemente dimorfos; anteras oblongas uniporosas, conectivo curtamente ou não prolongado abaixo da tecas, raramente com prolongamento dorso-basal; ovário semi-ínfero a totalmente ínfero, (2-)3-(5)10-locular. Baga subglobosa envolvida pelo hipanto e cálice persistentes. Sementes numerosas ovóides, testa lisa ou tuberculada.

3.1. Clidemia capitellata (Bonpl.) D.Don, Mem. Wern. Soc. 4 (2): 307.1823.

Arbustos 0,5-2 m., ramos e inflorescência densamente setosos com tricomas aglandulares de 2-5(8) $\mathrm{mm}$ compr. Folhas com pecíolo 1-2 cm compr.; lâmina 8-11 cm compr., 4-7 cm larg., oval-elíptica, ápice curtamente acuminado, base obtusa, membranácea e densamente ciliado-serrulada, moderadamente setosa em ambas as faces, tricomas da face abaxial 2-4 mm compr., 5-7 nervuras acródromas basais. Inflorescência racemosa lateral. Flores 5-meras, geralmente sésseis, bractéolas 2-4 mm compr., 1,2 mm larg., hipanto ca. $3 \mathrm{~mm}$ compr., lacínias 0,7-1,5 mm compr, ciliadas. Pétalas 4,5-5 mm compr., 2,7-3,2 mm larg., obovado-oblongas, brancas, glabras; anteras 2-2,3 mm compr.,oblongas, conectivo não prolongado. Ovário 5-locular, semi-ínfero, com tricomas glandulares no ápice. (Fig. 1. G-H).

$$
\text { Esteves et al. CFCR } 13488 \text { (SPF, UEC). }
$$

Espécie com distribuição neotropical, em cerrados e campos rupestres, no interior de clareiras, bordas das florestas e áreas perturbadas (Wurdack \& Renner 1993), desde o sul do México até o sudeste do Brasil, incluindo todas as Guianas. Em Grão-Mogol foi coletada com flores em setembro, em campo cerrado de solo arenoso. As variedades capitellata e dependens, distiguem-se apenas pelo maior comprimento dos tricomas na face abaxial das folhas nesta última.

\section{Comolia DC.}

Arbustos ou subarbustos. Caule e ramos quadrangulares pilosos ou glabros. Folhas sésseis ou pecioladas, oval-elípticas a cordiformes, obovais ou estreitamente oblongas, margem inteira, serreada ou serreado-ciliada. Flores solitárias, em dicásios ou em panículas, axilares ou terminais. Flores 4-meras. Hipanto campanulado a oblongo; lacínias triangulares a oval-oblongas. Pétalas oblongas a obovadas, purpúreas, róseas ou mais raramente brancas. Estames 8, isomorfos ou subisomorfos; anteras oblongo-subuladas, abrindo por um único poro apical; conectivo sempre prolongado abaixo das tecas e apendiculado ventralmente, raro dorsalmente. Ovário súpero, 2(3)-4 locular. Cápsula globosa, loculicida, deiscente no ápice. Sementes numerosas, cocleadas a subcocleadas, testa tuberculada. 
4.1. Comolia sessilis (Spreng.) Triana., Trans. Linn. Soc. London 28: 37. 1871.

Subarbusto 0,4-1,3 m alt. Caule e ramos densamente piloso-glandulosos assim como ambas as faces das folhas, hipanto, cálice, brácteas e bractéolas. Folhas sésseis ou com pecíolo até $2 \mathrm{~mm}$ compr., lâmina 5-11(15) mm compr, 4-9(13) mm larg., estreita a amplamente cordiforme, base cordada, ápice agudo, margem inteira a denteada, 3-7 nervuras acródromas basais. Flores isoladas, axilares, subsésseis, formando pseudo-espigas no ápice dos ramos; brácteas 4-10 cm compr, 4-8 cm larg, semelhantes às folhas; hipanto $5 \mathrm{~mm}$ compr., lacínias 4-5 mm compr, $1 \mathrm{~mm}$ larg, lineartriangulares. Pétalas 14-17 mm compr., 6-7 mm larg., violáceas, oblongo-lanceoladas, base atenuada, ápice acuminado. Estames subisomorfos; antessépalos: filetes 5-8 mm compr., anteras $6 \mathrm{~mm}$ compr., linear-oblongas; conectivo prolongado abaixo das tecas $5 \mathrm{~mm}$, apêndice bituberculado $0,3 \mathrm{~mm}$ compr.; antepétalos: filetes ca. $4 \mathrm{~mm}$ compr., anteras $5 \mathrm{~mm}$ compr., linear-oblongas; conectivo prolongado ca. $2 \mathrm{~mm}$, apêndice bituberculado, 0,3 mm compr. Ovário 4-locular; cápsula 5 mm compr. Sementes cocleadas. (Fig. 1. I-J).

Cavalcante et al. CFCR 9649 (SPF, UEC), Cordeiro et al. CFCR 836 e 10044 (SPF, UEC), Hatschbach 4133 (SPF), Pirani et al. CFCR 908, 8350, 10797 e 10803 (SPF, UEC).

Comolia sessilis é endêmica no estado de Minas Gerais e ocorre nos campos rupestres na região do cerrado, em solos úmidos. Aparentemente esta espécie está distribuída de maneira disjunta, entre as porções norte e sul da Serra do Espinhaço.

\section{Lavoisiera DC.}

ALMEDA, F. \& MARTINS, A.B. 2001. New combinations and new names in some Brazilian Microlicieae (Melastomataceae), with notes on the delimitation of Lavoisiera, Microlicia, and Trembleya. Novon 11(1): 1-7 .

Arbustos e subarbustos eretos, raro decumbentes, glabros ou pilosos. Ramos folhosos no ápice e em geral desnudos na base, algumas vezes folhosos até a base. Folhas imbricadas ou não, sésseis, carenadas ou planas; lâmina com margem inteira, ciliada ou serreado-ciliada, frequentemente calosa, nervuras 3-5(-9) acródromas basais, em geral apenas a central conspícua. Flores 5-6(-8-10) meras, isoladas, aos pares ou em dicásios reduzidos, axilares e terminais, sésseis ou pediceladas; brácteas e bractéolas geralmente presentes; hipanto oblongo a campanulado, constrito ou não na região subapical; cálice com lacínias linear-triangulares, lanceoladas, oblongas a suborbiculares; pétalas róseas a púrpuras ou magenta, brancas ou raro amarelas, ocasionalmente bicolores, róseas com a base amarelada; estames 10-12(-16-20), dimorfos; anteras ovóide-oblongas, retas, curtamente rostradas, uniporosas; conectivos prolongados, ventralmente apendiculados; ovário ínfero a semi-ínfero, (2-)4-8-locular, glabro; estilete glabro. Cápsula deiscente na base, envolvida pelo hipanto persistente; sementes numerosas, ovóideoblongas, levemente curvas.

1. Flores em dicásios congestos, simulando inflorescências glomeruladas L. mellobarretoi

1'. Flores solitárias terminais

2 Folhas oval-oblongas, (5-8 compr, 3-7,5mm larg.); ovário 6-locular L. imbricata

2'. Folhas lineares (6-11 compr., 1'5-2 mm larg.); ovário 4-5 locular L. chamaepitys

5.1. Lavoisiera chamaepitys A.St.-Hil. ex Naudin, Ann. Sci. Nat. Bot, ser.3, 2: 153. 1844.

Subarbusto ereto, pouco ramificado ou ocasionalmente cespitoso, 0,3-0,5(-1,2) m alt., totalmente glabro. Ramos rígidos, subquadrangulares, nós com cicatrizes foliares conspícuas. Folhas sésseis, densamente imbricadas; lâmina 6-7(11) $\mathrm{mm}$ compr., 1,5-2 mm larg., cartácea a coriácea, base subarredondada, ápice subulado e pungente, margem inteira, 1-nervura. Flores 5-6 meras, solitárias, terminais; brácteas 4-6, sésseis, semelhantes às folhas. Hipanto 3-4 mm, campanulado; lacínias do cálice 5-6 mm compr., 2-3 mm larg., oval- oblongas, ápice cuspidato, margem inteira ou ocasionalmente erosa. Pétalas 1,3(-2) cm compr., $0,7(-1) \mathrm{cm}$ larg., róseas, amareladas na base. Estames dimorfos; antessépalos: filetes 6-7 $\mathrm{mm}$ compr., anteras 3,5 $\mathrm{mm}$ compr., púrpuras, conectivo 5-6 mm compr., apêndice ca. 1,5 mm compr., obscuramente bilobado; antepétalos: filetes $5 \mathrm{~mm}$ compr., anteras $2,5 \mathrm{~mm}$ compr., púrpuras, conectivo ca. $1 \mathrm{~mm}$ compr., apêndice 0,5-1 mm compr. Ovário 4-5-locular, semi-ínfero. Cápsula ca. 0,5 cm compr.; sementes numerosas, ca. $1 \mathrm{~mm}$ compr., oblongas, testa foveolada. (Fig. 1. K).

\section{Kral et al. 72691 (SPF); Zappi et al. CFCR 8527 (SPF).}

Endêmica na Serrra do Espinhaço, na região de Diamantina e em Grão-Mogol, onde cresce em locais arenosos próximos a rios. Caracteriza-se pelas folhas lineares e pun- 
gentes, inicialmente imbricadas e eretas na base dos ramos, tornando-se depois caracteristicamente patentes e recurvas no ápice dos ramos. A espécie é pouco abundante localmente e poucos indivíduos foram coletados até o momento. Coletada com flor em julho.

\subsection{Lavoisiera imbricata (Thunb.) DC., Prodr. 3: 103.1828.}

Arbustos ou subarbustos eretos 0,3-1,2 m alt. Ramos glabros. Folhas sésseis, densamente imbricadas; lâmina 5-8 mm compr., $3-7,5 \mathrm{~mm}$ larg., carenada, oval a oblonga, ápice pungente, margem calosa, serrulado-ciliada, glabra nas duas faces, 1 nervura evidente. Flores 6-meras, terminais, solitárias; brácteas numerosas, semelhantes às folhas. Hipanto 3-5 $\mathrm{mm}$ compr., 2,5 mm larg., campanulado a levemente constrito no ápice, variadamente pubérulo ou glabro. Lacínias 2,5-9 mm compr., 2-4 mm larg., oval-oblongas, espatuladas ou suborbiculares, verdes, esbranquiçadas ou avermelhadas quando jovens, acinzentadas no ápice e raro escariosas na maturidade, margens inteiras ou diversamente ciliadas. Pétalas 0,8-2,7 cm compr., 0,4-1 cm larg., róseas, amareladas ou esbranquiçadas na base, raramente brancas. Estames dimorfos; antessépalos: filetes ca. $7 \mathrm{~mm}$ compr., anteras $3 \mathrm{~mm}$ compr., amarelas, conectivo prolongado ca. $5 \mathrm{~mm}$, apêndice $1 \mathrm{~mm}$ compr., bilobado, amarelo; antepétalos: filetes $6 \mathrm{~mm}$ compr., anteras $2,5 \mathrm{~mm}$ compr., apêndice $0,5 \mathrm{~mm}$ compr., amarelo. Ovário 6-locular, $4 / 5$ a totalmente ínfero. Cápsula 3-6 mm compr..Sementes 0,8-1 mm compr., oblongas, reniformes, testa foveolada. (Fig. 1. L-M).

Barreto et al. CFCR 11954 (SPF); Kral et al. 72710 (SPF).

Amplamente distribuída desde o norte do Paraná e sul de São Paulo, Rio de Janeiro e Espírito Santo, onde é pouco freqüente, através das serras de Minas Gerais (Planalto Sul-Mineiro e principalmente Serra do Espinhaço) até Goiás e Bahia (Chapada Diamantina) onde é localmente comum em habitats de campo rupestre, campos graminosos sazonalmente alagados, bordas de matas de galeria, áreas perturbadas e campos úmidos entre 600-1800 m de altitude. Na maioria de sua distribuição tende a ser restrita a áreas úmidas, tendo sido menos frequentemente coletada em cerrado onde geralmente é restrita a bordas de rios. Coletas com flores e frutos foram feitas ao longo de todo o ano. Esta espécie é a que apresenta distribuição mais ampla no gênero e exibe um padrão de variação extremamente complexo, com uma multiplicidade de formas que levaram à descrição de inúmeras outras espécies que estão sendo a ela sinonimizadas (Martins \& Almeda, em prep.). Pode ser reconhecida pelas folhas densamente imbricadas, flores 6-meras e ovário 6-locular. Em Grão-Mogol foi coletada em solo arenoso e na margem de cursos d'água.

5.3. Lavoisiera mellobarretoi Markgr., Notizbl. Bot. Gart. Berlin-Dahlem 15: 220-221. 1940.

Subarbustos 0,5-2,5 m alt. Ramos glabros, nós com tricomas glandulares curtos e vináceos. Folhas sésseis, laxas a subimbricadas; lâmina 3,5-8 cm compr., (0,7)1-3 cm larg., coriácea, oblonga a eliptica, base arredondada a subauriculada, ápice obtuso a agudo, glabra, às vezes com longos tricomas esparsos na face adaxial, margem inteira a esparsamente serrulada, 3-7 nervuras. Inflorescências terminais, congestas, geralmente dicásios com ca 8 flores simulando um glomérulo, brácteas numerosas 1,5-3,5 cm compr., 1-2 cm larg., subsésseis, ovais, bractéolas 1-1,5 cm compr., 0,6$0,8 \mathrm{~cm}$ larg., ovais. Flores 5-meras. Hipanto ca. $1 \mathrm{~cm}$ compr., esparsamente piloso no ápice; lacínias persistentes 5-6 mm compr., 2-3 mm larg., triangulares. Pétalas 2-2,5 cm compr., $1-1,2 \mathrm{~cm}$ larg, róseas a lavanda, amareladas na base. Estames antessépalos: filetes $0,8-1 \mathrm{~cm}$ compr., anteras $4-5 \mathrm{~mm}$ compr., oblongas, conectivo prolongado $5 \mathrm{~mm}$, apêndice 1,5-2 mm compr., emarginado a bilobado; estames antepétalos: filetes $0,7 \mathrm{~mm}$ compr., anteras $4 \mathrm{~mm}$ compr., oblongas, conectivo pouco prolongado $1-1,5 \mathrm{~mm}$, apêndice $0,6 \mathrm{~mm}$ compr., inconspícuo. Ovário 5-locular. Cápsula ca. $1 \mathrm{~cm}$ compr., globosa. (Fig. 1. N-O).

Bidá et al. CFCR 11938 (SPF, UEC); Cordeiro et al. CFCR 961 (SPF, UEC); Hatschbach 41334 (UEC); Hatschbach et al. 54273 (UEC); Leitão-Filho et al. 7891 (UEC); Pirani et al. CFCR 10764 (SPF, UEC).

Endêmica de Grão-Mogol, onde foi coletada nos campos rupestres, em locais mais úmidos próximos a córregos e rios, em altitudes em torno de $1000 \mathrm{~m}$. Distingue-se das demais espécies do gênero na região pelo porte arbustivo até $2,5 \mathrm{~m}$, ramificado a ca. $40 \mathrm{~cm}$ da base, folhas planas e flores agregadas em inflorescências glomeruladas congestas envolvidas por brácteas numerosas.

\section{Leandra Raddi}

Subarbustos 0,2- $1 \mathrm{~m}$ ou árvores até $8 \mathrm{~m}$ alt., raramente lianas. Folhas sésseis ou pecioladas, membranáceas a coriáceas, margem geralmente ciliada, isomorfas. Flores em geral 5-meras, raro 4-6 ou 7-meras, pouco vistosas, geralmente em panículas terminais ou pseudolaterais. Hipanto globoso, campanulado, urceolado ou lageniforme. Lacínias externas do cálice bem desenvolvidas, internas em geral inconspícuas. Pétalas brancas, mais raramente róseas ou amareladas, lineares ou oval-lanceoladas com ápice agudo, usualmente glabras. Estames isomorfos, glabros, anteras usualmente oblongas, um único poro, conectivo não 
ou pouco prolongado, normalmente não apendiculado. Ovário 2-5, mais raramente 6-7-locular, semi-ínfero ou ínfero, glabro ou pubescente no ápice. Fruto baga, azulado ou atropurpúreo, raro branco ou esverdeado. Sementes numerosas, pequenas, geralmente angulado-piramidais e lisas, ocasionalmente ovais e tuberculadas.

1. Ramos densamente velutinos, lâmina 9-10,5 cm compr, 3,5-5 cm larg L. aurea

1'. Ramos densamente hirsutos, lâmina 6-7 cm compr, 2-3 cm larg. L. cancellata

6.1. Leandra aurea (Cham.) Cogn. in Mart., Fl. bras. 14(4): 142. 1886.

Arbustos até $2 \mathrm{~m}$ alt. Ramos densamente velutinos com tricomas dendríticos curtos. Folhas com pecíolo 1-2 cm compr., lâmina 9-10,5 cm compr, 3,5-5 cm larg., cartácea, oval-lanceolada, base arredondada, ápice acuminado, margem crenulado-ciliada, face adaxial levemente bulada, setosa, face abaxial vilosa, com tricomas dendríticos estrelados, 5 nervuras acródromas basais. Panícula de glomérulos terminal ca. $20 \mathrm{~cm}$ compr. Flores 5 -meras, sésseis. Hipanto $5 \mathrm{~mm}$ compr., oblongo, densamente viloso-tomentoso, lacínias externas $2 \mathrm{~mm}$ compr., triangulares, internas inconspícuas. Pétalas ca. $3 \mathrm{~mm}$ compr, $2 \mathrm{~mm}$ larg, brancas, lanceoladas, ápice agudo. Estames 10, isomorfos, filetes ca. 3 $\mathrm{mm}$, anteras ca. $2 \mathrm{~mm}$, curvas, conectivo não prolongado, espessado no dorso. Ovário 3-locular, semi-ínfero, ápice esparsamente piloso. Baga ca. $5 \mathrm{~mm}$ compr. Sementes ca. 0,7 mm compr., subovóides.

Assis et al. CFCR 11431 (SPF).

Amplamente distribuída nos cerrados e campos rupestres na Serra do Espinhaço, no planalto sul-mineiro, em Minas Gerais, Goiás, Espírito Santo, na Chapada Diamantina, Bahia, Paraná e no leste do estado de São Paulo. Existe o registro de uma coleta no Rio Grande do Sul. Em Grão-Mo- gol foi coletada próximo a riacho, entre rochas. Floresce de setembro a novembro.

6.2. Leandra cancellata Cogn. in Mart., Fl. bras. 14(4): 103. 1886.

Arbustos ca. 1,3 m alt. Ramos densamente hirsutos com tricomas dendríticos curtos. Folhas com pecíolo $1-1,5 \mathrm{~cm}$ compr., lâminas 6-7 cm compr, 2-3 cm larg., cartáceas, oval-lanceoladas, base arredondada cordada, ápice acuminado, margem ciliada, face adaxial híspida, levemente bulada, face abaxial com tricomas dendríticos esparsos e setulosos nas nervuras, 5 nervuras acródromas basais. Panicula de glomérulos ca $12 \mathrm{~cm}$ compr., terminal. Flores 5-meras, sésseis. Hipanto ca. $4 \mathrm{~mm}$ compr., oblongo, esparsamente setoso-dentrítico no ápice e na base, lacínias externas ca $3 \mathrm{~mm}$ compr., linear-triangulares, internas inconspícuas. Pétalas $2 \mathrm{~mm}$ compr, $2 \mathrm{~mm}$ larg., brancas, lanceoladas, ápice agudo. Estames 10, isomorfos, filetes ca. $3 \mathrm{~mm}$ compr., anteras ca. $3 \mathrm{~mm}$ compr., subuladas, conectivo não prolongado, espessado no dorso. Ovário (2) 3-locular, semi-ínfero, ápice esparsamente piloso.

Pirani et al. CFCR 12687 (SPF, UEC).

Ocorre em campos e campos rupestres na Bahia e em Minas Gerais na Serra do Cipó, Serra do Caraça e Tiradentes, além de Grão-Mogol.

\section{Macairea DC}

RENNER, S. S. 1989. Systematic studies in the Melastomataceae: Bellucia, Loreya, and Macairea. Mem. New York Bot. Gard. 50: $1-112$.

Arbustos ou subarbustos, raro arvoretas ou ervas. Ramos jovens com indumento variado, adultos glabrescentes e decorticantes. Folhas pecioladas; lâmina elíptica, oval, oboval, cordada ou linear, 3-9 nervuras acródromas basais e suprabasais. Panículas tirsóides, terminais; brácteas semelhantes às folhas, bractéolas lanceoladas. Flores 4-meras, pediceladas. Hipanto oblongo a campanulado; cálice simples, lacínias triangulares a lanceoladas; pétalas obovadas, róseas ou magenta, raro brancas ou púrpura, base branca tornando-se púrpura após a antese; estames dimorfos, antessépalos maiores com tricomas glandulares ao longo do filete, conectivo prolongado abaixo das tecas expandindo-se na inserção do filete, anteras com ápice uniporoso; ovário súpero, 2-4-locular. Cápsula loculicida deiscente no ápice; sementes numerosas cocleadas ou poliédricas, testa tuberculada ou reticulado-foveolada. 


\subsection{Macairea radula DC., Prodr.3: 109. 1828.}

Arbustos até 1,5 m alt. Ramos jovens, pecíolos, pedúnculos, face abaxial das folhas e brácteas, hipanto, face adaxial das lacínias do cálice e das bractéolas densamente seríceoglandulosas. Folhas com pecíolo 0,5-1 cm compr.; lâmina 6-6,5 cm compr, 3,5-4 cm larg., base atenuada, ápice obtuso, margem inteira, face adaxial hirsuto-glandular, 3 nervuras acródromas suprabasais, 1 par marginal acródromo basal menos evidente ou ausente. Inflorescência até $22 \mathrm{~cm}$ compr., tirsóide, terminal; bractéolas 4-6 mm compr., 1,5 mm larg. Flores subsésseis; hipanto $3 \mathrm{~mm}$ compr., oblongo-campanulado, lacínias do cálice $5 \mathrm{~mm}$ compr., lanceoladas. Pétalas $8,5 \mathrm{~mm}$ compr., 5,5 $\mathrm{mm}$ larg, púrpuras. Estames 8, dimorfos, antessépalos: anteras $4 \mathrm{~mm}$ compr., conectivo prolongado 2 $\mathrm{mm}$ abaixo das tecas, antepétalos: anteras $3,5 \mathrm{~mm}$ compr., conectivo prolongado 1,5 mm; ovário 4-locular, $3 \mathrm{~mm}$ compr. Cápsula ca $3 \mathrm{~mm}$ compr.; sementes $0,5 \mathrm{~mm}$ de compr., testa tuberculada. (Fig. 1. P-R).
Cordeiro et al. CFCR 11317 (SPF, UEC); Esteves et al. CFCR 13411 (SPF, UEC); Harley et al. 25063 (SPF, UEC); Mello-Silva et al. CFCR 8334, 9866 e 10002 (SPF, UEC).

Material adicional: Minas Gerais: Simão et al. 72690 (SPF, UEC).

Espécie amplamente distribuída nos cerrados, campos rupestres e matas de galeria a estes associados, ocorrendo em todo o Planalto Central do Brasil e mais raramente no nordeste. Encontrada comumente na Serra do Espinhaço, em Minas Gerais e Chapada Diamantina na Bahia, além de outras localidades no centro-oeste e sudeste, sendo mais raras no nordeste. Em Grão-Mogol foi encontrada nas margens de cursos d'água. Coletada com flores de julho a novembro. Pode ser facilmente identificada pela associação de características como folhas longamente pecioladas com indumento áspero na face adaxial e a constante presença de galhas avermelhadas, arredondadas, e com superfície de aspecto muricado ou piloso.

\section{Marcetia DC.}

MARTINS, A.B. 1995. Marcetia hatschbachii (Melastomataceae: Tibouchineae): uma nova espécie de Grão-Mogol, Minas Gerais, Brasil. Bol. Bot. Univ. São Paulo 14: 43-47 .

Arbustos e subarbustos eretos, cespitosos ou prostrados, raramente ervas, com xilopódio algumas vezes bem desenvolvido. Ramos quadrangulares a subcilíndricos, pilosos, glutinosos ou glabros, usualmente decorticantes na base. Folhas opostas, decussadas, raramente em pseudofascículos, pecioladas ou sésseis, planas ou revolutas, membranáceas a coriáceas, inteiras a obscuramente serruladas, ciliadas ou calosas nas margens, geralmente pilosas nas duas faces ou totalmente glabras, (1-)311(15) nervuras. Flores 4-meras, isoladas, pediceladas ou subsésseis, bracteoladas ou não; hipanto campanulado a urceolado; cálice com lacínias linear-oblongas a triangulares; pétalas em diversas tonalidades de lilás, rosa a púrpura, magenta, vermelho, branco e amarelo; estames 8, isomorfos ou levemente dimorfos; anteras com tecas linear-oblongas, ápice uniporoso; conectivo curtamente prolongado e inconspicuamente apendiculado; ovário súpero ou semi-súpero, glabro, 4-3(2) locular. Cápsula envolvida pelo hipanto persistente, deiscente no ápice; sementes geralmente numerosas, cocleadas ou subcocleadas.

1. Folhas com pecíolo $0,5 \mathrm{~mm}$ de compr.; flores com pedicelo $1 \mathrm{~mm}$ compr M. taxifolia

1'. Folhas com pecíolo 2-4(-5) mm compr.; flores com pedicelo 4-5 mm compr. M. hatschbachii

\subsection{Marcetia hatschbachii A.B. Martins, Bol. Bot. Univ. São} Paulo 14: 44. 1995.

Subarbusto 30-40 cm alt. Ramos, pecíolos, face adaxial das folhas, bractéolas, hipanto e lacínias com tricomas pubérulo-glandulosos. Pecíolo 2-4-(-5) mm compr.; lâmina 0,8-1,5 cm compr., 0,3-0,5 cm larg., membranácea, oblonga a lanceolada, base obtusa a atenuada, ápice obtuso ou arredondado, margem inteira ciliado-glandulosa, face abaxial tomentoso-glandulosa, nervuras 3 , laterais muito delgadas e visíveis apenas na face inferior. Flores isoladas, axilares, curtamente pedunculadas e longamente pediceladas; pedúnculo ca. 1,5 mm compr., pedicelo 4-5 mm compr.; bractéolas 3-4 mm compr., 1-2 mm larg, semelhantes às folhas; hipanto 3-4 mm compr.; cálice persistente, lacínias 1,5-2 mm com- pr., ca. $0,5 \mathrm{~mm}$ larg., lineares. Pétalas $7-8 \mathrm{~mm}$ compr., $3 \mathrm{~mm}$ larg., lilases, estames isomorfos; filetes ca. $6 \mathrm{~mm}$ compr.; anteras 2,5-3 mm compr. oblongas, retas; longitudinalmente sulcadas, conectivo espessado na base, prolongado abaixo das tecas, levemente tuberculado no dorso, aurículas ventrais truncadas; ovário 4-locular; cápsula 3-3,5 mm compr.; sementes ca. 0,4 mm compr., subcocleadas, foveoladas a irregularmente costadas no dorso.

Hatschbach 41511 (MBM, holótipo; US, isótipo); Simão-Bianchini et al. CFCR 13026 (SPF, UEC).

Espécie rara e endêmica em Grão-Mogol, onde ocorre em campo rupestre com afloramento de rochas quartzíticas e areníticas. Coletada com flores e frutos em junho e julho. 
Próxima de $M$. taxifolia, que ocorre em simpatria, mas difere pelas anteras oblongas, retas, com tecas longitudinalmente sulcadas, pétalas estreitas e comprimento do pecíolo e pedicelo.

\subsection{Marcetia taxifolia (A. St.-Hil.) DC., Prodr. 3: 124. 1828.}

Arbustos e subarbustos (15-) 40-150 (-300) cm alt. Ramos, folhas, pedicelo, hipanto e cálice recobertos por indumento muito variável. Folhas sésseis ou com pecíolos ca. 0,5 mm compr.; lâmina (3-) 5-8 (-12) mm compr., 1-3 (-5) $\mathrm{mm}$ larg., membranácea a subcoriácea, oblongo-lanceolada, oval-cordiforme ou linear-oblonga, base subcordada, ápice mucronulado ou arredondado, margem às vezes revoluta, (1-) 3-5 (-7) nervuras. Flores isoladas nas axilas das folhas apicais dos ramos, simulando inflorescências racemiformes folhosas; pedicelo ca. $1 \mathrm{~mm}$ compr. Bractéolas (1-) 2-3 (-4 $\mathrm{mm}$ ) compr. , 0,5-1 mm larg. Hipanto (2-) 3 (-5) mm compr, oblongo, campanulado a suburceolado; lacínias (1-) 2-3,5 mm compr., 0,5-1 mm larg., linear-triangulares. Pétalas (4-) 5 (-7) mm compr., (2-)3-4,5 mm larg., liláses, róseas, roxas, purpúreas ou brancas, oval-elípticas. Estames isomorfos; an- te-sépalos: filetes 5,5-9 mm compr., anteras 3-5,5mm compr.; linear-oblongas, ligeiramente arqueadas, conectivo espessado na base e prolongado ventralmente em aurículas conspícuas, raramente tuberculado no dorso; antepétalos: filetes 4-6 mm compr.;. 2,5-4 mm compr., ovário 4-locular; cápsula 3-4mm compr.; sementes ca. 0,4 mm compr., arredondadas, cocleadas, tuberculadas a foveoladas. (Fig. 1. S-T).

Cavalcanti et al. CFCR 8423 (SPF); Giulietti et al. CFCR 9811 (SPF, UEC)

Amplamente distribuída no Brasil, onde pode ser encontrada desde a Paraíba até o Paraná e também nas montanhas e cerrados da região centro-oeste, embora em alguns estados esteja representada por poucos indivíduos. Ocorre com menos frequência na Venezuela, Guiana e Colombia. Populações dessa espécie tem grande tolerância ecológica, crescendo em ambientes tão diversos como montanhas a $3.000 \mathrm{~m}$ de altitude, na Venezuela, e campos rupestres nas serras, ou em restingas ao nível do mar no Brasil. É um táxon muito variável ao qual devem ser sinonimizadas um grande número de espécies e variedades. Floresce e frutifica ao longo de todo o ano.

\section{Merianthera Kuhlm.}

Arbustos com indumento variável ou glabros. Folhas opostas, pecioladas, nervação acródroma. Flores isoladas ou em panículas terminais; 5-meras; hipanto campanulado; cálice duplo, regularmente lobado, geralmente com lacínias externas pouco conspícuas, persistente; pétalas roxas ou róseas, obovais, ápice arredondado ou truncado; estames dimorfos, filetes geralmente achatados, glabros, anteras de oblongas a subuladas, uniporosas, conectivo levemente ou não prolongado, com apêndice dorsal ascendente; ovário 5-locular, ínfero, estilete glabro, filiforme. Fruto capsular, sementes numerosas, cuneadas.

9.1. Merianthera sipolisii (Glaz. \& Cogn.) Wurdack, Phytologia 55: 133. 1984.

Arbusto 2-3m alt. Ramos tomentosos. Folhas com pecíolo 1-2 cm; lâmina 8-11 cm compr., 6-9 cm larg., membranácea, oval a oval-lanceolada, base cordada, ápice agudo a obtuso, margem inteira, face abaxial tomentosa com tricomas entremeados e tricomas glandulares curtos, face adaxial esparsamante tomentosa a glabra, 5-7 nervuras acródromas basais. Inflorescências paniculadas, pedicelo $5 \mathrm{~mm}$ compr.; hipanto campanulado, ca. $5 \mathrm{~mm}$ compr.; lacínias $4 \mathrm{~mm}$ compr., triangulares. Pétalas $2 \mathrm{~cm}$ compr., $1 \mathrm{~cm}$ larg., liláses, obovadas; estames dimorfos; antesépalos (pré-antese): filetes ca. $7 \mathrm{~mm}$ compr.; anteras $5 \mathrm{~mm}$ compr., oblongas; conectivo prolongado abaixo das tecas ca. $1 \mathrm{~mm}$, apêndice dorsal ca. $5 \mathrm{~mm}$ compr.; antepétalos (pré-antese): filetes ca. $7 \mathrm{~mm}$, anteras ca. $5 \mathrm{~mm}$ compr., oblongas; conectivo prolongado ca 0,8 $\mathrm{mm}$ abaixo das tecas, apêndice dorsal ca $4 \mathrm{~mm}$ compr.; ovário 5-locular. (Fig. 1. U-W).
Cordeiro et al. CFCR 944 (SPF, UEC); Mello-Silva et al. CFCR 9678 (SPF, UEC).

Espécie restrita a áreas próximas a Diamantina e GrãoMogol, onde cresce em campo rupestre com afloramento de rochas quartzíticas e areníticas. Coletada com flores entre fevereiro e abril e com frutos em abril. Caracteriza-se pelas folhas cordadas, grandes e com indumento ferrugíneo. Pertencia inicialmente ao gênero Meriania Sw., mas Wurdack (1984) estabeleceu uma nova combinação transferindo a espécie para o gênero Merianthera, devido ao seu ovário ínfero. As populações de Diamantina e Grão-Mogol são levemente diferentes: em Diamantina as folhas têm face abaxial com tricomas mais esparsos, que conferem às mesmas um aspecto menos discolor do que as folhas das coletas de Grão-Mogol, que têm tricomas mais densamente dispostos. É possível que estas populações sejam distintas em nível subespecífico. 


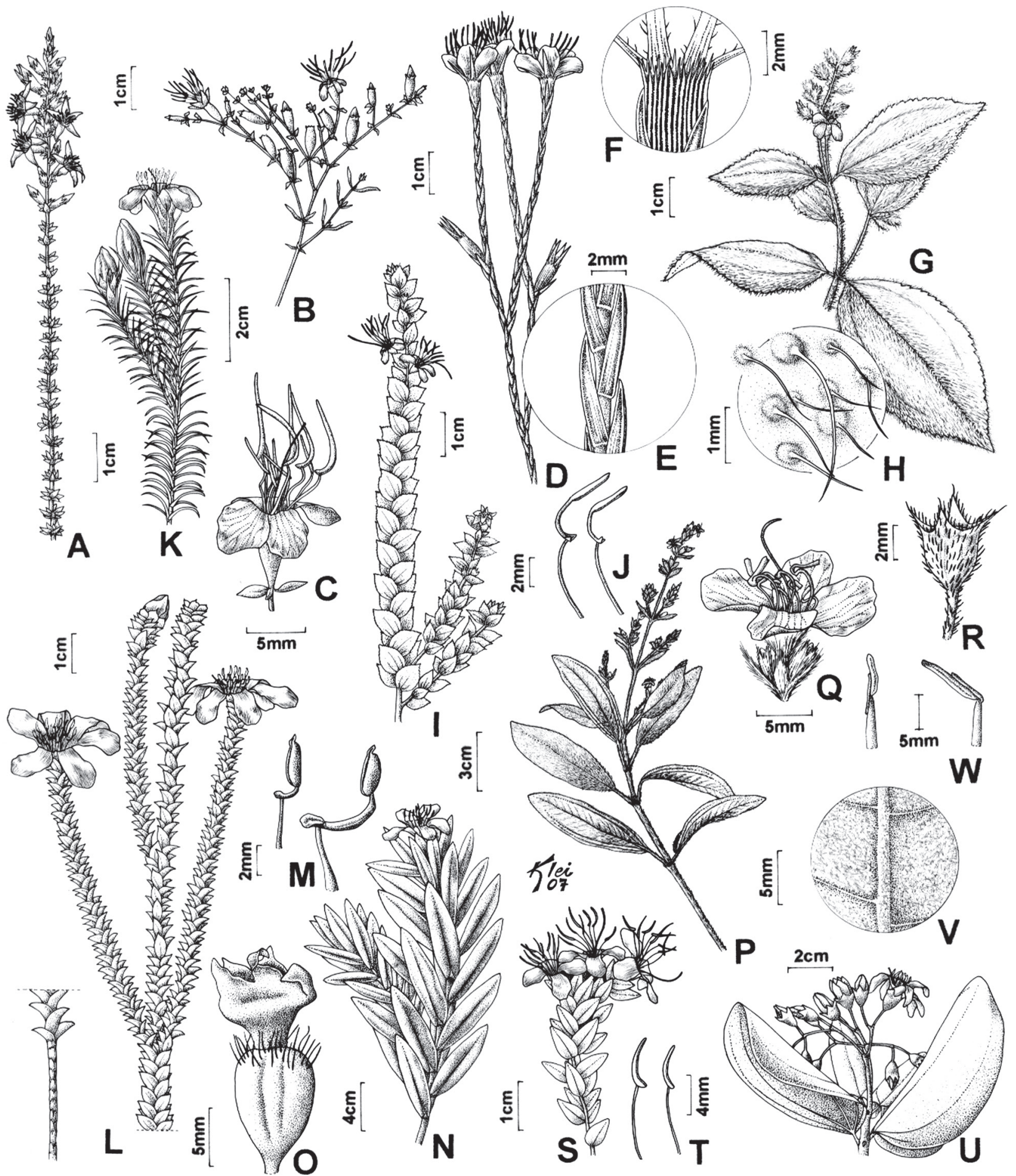

Fig. 1. MELASTOMATACEAE: A. Cambessedesia espora: ápice do ramo com inflorescência espiciforme (Harley et al. CFCR 6447); B-C. Cambessedesia hilariana: B. Ápice do ramo; C. Flor (Mello-Silva CFCR 9648); D-F: Chaetostoma armatum: D. Aspecto do ramo; E. Folhas imbricadas; F. Hipanto com coroa apical de cerdas (Mello-Silva \& Pirani CFCR 10824); G-H. Clidemia capitellata: G. Ápice do ramo com inflorescência; H. Tricomas foliares (Pirani et al. CFCR 13521); I-J. Comolia sessilis: I. Ramo com inflorescêcia espiciforme; J. Estames dos dois ciclos (Cavalcanti et al. CFCR 9649); K. Lavoisiera chamaepitys: Ápice do ramo (Zappi et al. CFCR 8527); L-M. Lavoisiera imbricata: L. Ápice dos ramos; M. Estames dos dois ciclos (Kral et al. 72710); N-O. Lavoisiera mellobarretoi: N. Aspecto do ramo; O. Fruto (Zappi et al. CFCR 13117); P-R. Macairea radula: P. Ápice do ramo com inflorescência; Q. Flor; R. Fruto (Cordeiro et al. CFCR 11317); S-T. Marcetia taxifolia: S. Ápice do ramo; T. Estames dos dois ciclos (Giulietti et al. CFCR 9811); U-W. Merianthera sipolisii: U. Ápice do ramo com inflorescência; V. Detalhe da face abaxial da folha; W. Estames dos dois ciclos (Mello-Silva et al. CFCR9678). 
10. Miconia Ruiz et Pav.

MARTINS, A.B., SEMIR, J., GOLDENBERG, R. \& MARTINS, E. 1996. O gênero Miconia no Estado de São Paulo. Acta bot. bras.10(2): 267-316.

GOLDENBERG, R. 2004. O gênero Miconia (Melastomataceae) no Estado do Paraná. Acta bot. bras. 18(4): 927-947.

GOLDENBERG, R. 2009. Miconia (Melastomataceae). In M.G.L. Wanderley et al. (eds.) Flora fanerogâmica do Estado de São Paulo. FAPESP. São Paulo, vol. 6.

WURDACK, J.J. 1962. Melastomataceae of Santa Catarina. Sellowia 14: 109-217.

WURDACK, J.J. 1976. Certamen Melastomataceis XXV. Phytologia 35(1): 1-13.

Arbustos ou árvores com indumento variável ou glabras. Folhas opostas ou verticiladas, pecioladas ou sésseis, nervação acródroma. Panículas terminais, raro com ramos adicionais axilares; inflorescências parciais dicasiais, glomeruladas, espiciformes ou escorpióides. Flores 5-meras, raro 4, 6 ou 8-meras; hipanto campanulado a cilíndrico; cálice simples ou duplo, em geral regularmente lobado e com lacínias externas pouco conspícuas, persistente ou caduco; pétalas arredondadas ou retusas no ápice, raro apiculadas; estames dimorfos ou isomorfos, filetes geralmente glabros, anteras de forma variável, uniporosas, raro 2 ou 4-porosas ou rimosas, conectivo simples ou basalmente prolongado, com ou sem apêndices dorsais ou ventrais; ovário (1-)2-5-locular, semi-ínfero a ínfero. Fruto bacáceo; 1 ou várias sementes, piramidais a ovais.

1. Folhas maduras com face abaxial densamente recoberta por tricomas

2. Panículas de glomérulos

3. Tricomas na face inferior das folhas estrelados e estrelado-estipitados ou dendríticos, sempre individualizáveis M. sclerophylla

3'. Tricomas na face inferior das folhas aracnóideos, de difícil individualização M. alborufescens

2'. Panículas escorpióides

4. Tricomas na face inferior das folhas aracnóideos, de difícil individualização M. albicans

4'. Tricomas na face inferior das folhas estrelados e estrelado-estipitados ou dendríticos, sempre individualizáveis 5. Folhas com 11,5-21 cm compr.; panículas ca. $35 \mathrm{~cm}$ compr. 5'. Folhas com 5-9,9 cm compr.; panículas ca. 3,7-7 cm compr. M. ferruginata

6. Ovário com ápice recoberto por tricomas estrelados; frutos com 1-3 sementes M. cubatanensis 6'. Ovário com ápice glabro; frutos com 7-10 sementes M. herpetica

1'. Folhas maduras com face abaxial glabra ou com tricomas esparsos, principalmente sobre as nervuras

7. Folhas com margem serreado-ciliada; anteras quadriporosas

8. Face inferior das folhas com tricomas simples, esparsos, principalmente próximos às nervuras; nervuras suprabasais. M. hirtella

8'. Face inferior das folhas glabra; nervuras basais M. theaezans

7'. Folhas com margem inteira, repanda, denticulada ou serrilhada, mas nunca ciliada; anteras uniporosas ou rimosas

9. Folhas com base abruptamente cuneada e decurrente; nervuras suprabasais (5-16 $\mathrm{mm}$ acima da base).

10. Lâmina 11-24 cm compr., 4,1-10 cm larg.; anteras uniporosas M. elegans

10'. Lâmina 4,3-10,8 cm compr., 1,3-2,8 cm larg.; anteras rimosas M. rimalis

9 '. Folhas com base obtusa, arredondada a subcordada; nervuras basais a curtamente suprabasais (até ca. $2 \mathrm{~mm}$ acima da base)

11. Ramos fortemente achatados e alados; folhas com margem hialina M. paradoxa

11'. Ramos não alados; folhas com margem não hialina

12. Folhas elípticas a ovais-elípticas, com margem inteira; estames brancos, anteras $1,5-1,8 \mathrm{~mm}$ compr. M. ligustroides

12'. Folhas lanceoladas a linear-lanceoladas, com margem serrilhada; estames amarelos, anteras 3-4 mm compr. M.langsdorffii

10.1. Miconia albicans (Sw.) Triana, Trans. Linn. Soc. London. 28: 116. 1871.

Arbustos 0,7-2 m alt. Ramos não alados, juntamente com pecíolos, face abaxial das folhas e hipanto com tricomas aracnóides (amorfos), canescentes ou ocráceos, densos. Pe- cíolo 0,5-0,9 cm compr.; lâmina 4,2-9,8 cm compr., 2,1-4 cm larg., elíptica a elíptico-lanceolada, base arredondada a subcordada, ápice obtuso, agudo ou acuminado, margem crenulada, nervuras 5 ou $5+2$, curtamente suprabasais (1-2 mm acima da base). Panículas escorpióides, 5,2-7,5 cm compr., 2,5-5,6 cm larg. Flores 5-meras; hipanto 2-2,4 mm compr.; 
cálice persistente, simples, lacínias largamente triangulares; estames brancos, anteras 2,3-2,5 mm compr., uniporosas, conectivo eglanduloso, ca. $0,2 \mathrm{~mm}$ prolongado abaixo das tecas, com projeção basal ampla, contínua da região ventral à dorsal (antessépalos) ou cálcar dorsal alargado e com 2 aurículas ventrais curtas (antepétalos); ovário 3-locular, glabro. Baga imatura rosada, madura verde-jade, ca. 30 sementes. (Fig. 2. A-B).

Campos et al. CFCR 13517 (SPF, UEC, US); Giulietti et al. CFCR 9842 (SPF, UPCB); Hatschbach 67896 (MBM); Mello-Silva \& Pirani CFCR 10859 (SPF, UEC, US).

Do México e Caribe até Paraguai e sul do Brasil (Paraná). Em Grão-Mogol ocorre em cerrado, em solo arenoso. Floresce e frutifica em maio, junho e setembro.

10.2. Miconia alborufescens Naudin, Ann. Sci. Nat. Bot., Ser. 3, 16: 160. 1850.

Arbustos 1-1,3 m alt. Ramos não alados, juntamente com pecíolos, nervuras da face abaxial das folhas e hipanto com tricomas dendríticos, superfície da face abaxial com tricomas aracnóides (amorfos), ambos canescentes ou ocráceos, densos. Pecíolo 0,5-1,2 cm compr.; lâmina 4,4-7,1 cm compr., 2,7-5,5 cm larg., oval, base cordada, ápice curtamente acuminado, margem crenulada, nervuras 5 ou $5+2$, curtamente suprabasais (1-2 $\mathrm{mm}$ acima da base). Panículas de glomérulos, 4,9-9,3 cm compr., 4-8 cm larg. Flores 5-meras; hipanto 1,5-2 mm compr.; cálice persistente, duplo, lacínias internas largamente triangulares, externas minutamente denticuladas; estames brancos, anteras 1,5-2 mm compr., uniporosas, conectivo eglanduloso, 0,6-0,8 $\mathrm{mm}$ (antessépalos) e 0,4-0,6 $\mathrm{mm}$ (antepétalos) prolongado abaixo das tecas, com projeção basal ampla, contínua da região ventral à dorsal (antessépalos) ou cálcar dorsal (antepétalos); ovário 3-locular, ápice com tricomas glandulares esparsos. Baga imatura vermelha, madura enegrecida, ca. 18 sementes. (Fig. 2. C).

Cavalcanti et al. CFCR 8303 (SPF, UPCB, US); Pirani et al. CFCR 12733 (SPF, UPCB); Pirani et al. CFCR 12822 (SPF, UPCB, US); Pirani et al. CFCR 13260 (SPF, UEC, US); Zappi et al. CFCR 8424 (SPF, UPCB, US).

Da Venezuela e Guianas até o Brasil, em Goiás e Minas Gerais. Em Grão-Mogol ocorre entre rochas ou em cerrado, em solo arenoso. Floresce e frutifica em junho, setembro e dezembro.

10.3. Miconia cubatanensis Hoehne, Anexos Mem. Inst. Butantan, Secç. Bot. 1(5): 139. 1922.

Arvoretas 3-7 m alt. Ramos não alados, juntamente com pecíolos, nervuras da face abaxial das folhas e hipanto com tricomas estrelado-estipitados com ápice achatado ou lepidotos, canescentes a ferrugíneos, densos mas caducos no hipanto. Pecíolo 0,5-1,5 cm compr.; lâmina 5-9,9 cm compr., 1-3,1 cm larg., lanceolada, base arredondada a aguda, ápice longo-acuminado, margem inteira e revoluta, nervuras 3 ou $3+2$, basais a curtamente suprabasais (até $2 \mathrm{~mm}$ acima da base). Panículas escorpióides, 3,7-5,1 cm compr., 2,6-2,9 cm larg. Flores 5-meras; hipanto ca. 1,5 mm compr.; cálice caduco, duplo, com lacínias internas largamente triangulares, externas denticuladas; estames brancos, anteras ca. 1,2 mm compr., uniporosas, conectivo eglanduloso, , 2,2-0,3 $\mathrm{mm}$ prolongado abaixo das tecas, com um cálcar dorsal pronunciado ou curto; ovário 3-locular, ápice com tricomas estrelados. Baga imatura verde, madura enegrecida, 1-3 sementes. (Fig. 2. D-F).

Pirani et al.CFCR 13019 (SPF, UPCB, US); Zappi et al. CFCR 12063 (SPF, UEC, US).

Desde a Bahia e Distrito Federal até Santa Catarina. Em Grão-Mogol ocorre no interior de matas. Frutifica em maio e junho. Esta espécie apresenta duas formas relativamente distintas: a primeira, que inclui o material-tipo (Hoehne 3341, K e SP), ocorre em formações pioneiras e florestas próximas ao litoral, e tem tricomas foliares claramente lepidotos. A segunda forma corresponde ao tipo de Miconia revoluta Miq (Widgren s.n., P; nome inválido e sinônimo de M. cubatanensis segundo Wurdack 1962), ocorre em regiões mais altas, nas Serras da Mantiqueira e formações florestais associadas a campos rupestres, e apresenta tricomas lepidotos misturados a tricomas estrelado-estipitados com ápice achatado. A ocorrência de intermediários impede o reconhecimento dessas formas como espécies distintas, mas as coletas de Grão-Mogol certamente pertencem à segunda forma.

10.4. Miconia elegans Cogn. in Mart., Fl. bras. 14(4): 312. 1888 .

Arbustos a arvoretas 2-5 m alt. Ramos não alados, juntamente com pecíolos, nervuras da face abaxial das folhas, superfície da face abaxial das folhas novas e hipanto com tricomas estrelados, ocráceos, densos a moderadamente densos, caducos. Pecíolo 0,8-1,5 cm compr.; lâmina 11-24 cm compr., 4,1-10 cm larg., elíptica, base abruptamente cuneada e decurrente, ápice curtamente caudado, margem inteira ou repanda, nervuras $3+2$, suprabasais (5-16 $\mathrm{mm}$ acima da base). Panículas escorpióides, 8,7-21 cm compr., 4,3-5,8 cm larg. Flores 5-meras; hipanto 3,2-3,7 mm compr.; cálice caduco, duplo, lacínias internas triangulares, externas minutamente denticuladas; estames brancos, anteras 2,1-2,5 mm compr., uniporosas, conectivo eglanduloso, não prolongado abaixo das tecas, ventralmente biauriculado ou com um cálcar dorsal; ovário 3-locular, ápice papiloso. Baga imatura vermelha, madura enegrecida, ca. 20 sementes. (Fig. 2. G-H).

Cordeiro \& Mello-Silva CFCR 10056 (SPF, UEC, US); Esteves et al. CFCR 13535 (SPF, UEC, US); Kawasaki et al. CFCR 8307 (SPF, UPCB, US); Pirani \& Mello-Silva CFCR 10876 (SPF, UPCB, US); Pirani et al. CFCR 12991 (SPF, UPCB, US). 
Desde o Pará, Tocantins e Bahia até São Paulo. Em GrãoMogol ocorre na beira de rios. Floresce e frutifica em maio, junho, setembro e novembro.

\subsection{Miconia ferruginata DC., Prodr. 3: 181.1828.}

Arvoretas 1,8 m alt. Ramos não alados, juntamente com pecíolos, face abaxial das folhas e hipanto com tricomas estrelados ou curtamente estrelado-estipitados, ocráceos, densos. Pecíolo 0,9-1,1 cm compr.; lâmina 11,5-21 cm compr., 6,4-10 cm larg., elíptica, base estreitamente arredondada, ápice obtuso ou acuminado, margem crenulada, nervuras 5+2, basais. Panículas escorpióides, ca. $35 \mathrm{~cm}$ compr., ca. $5,5 \mathrm{~cm}$ larg. Flores 5-meras; hipanto ca. $3 \mathrm{~mm}$ compr.; cálice caduco, duplo, lacínias internas triangulares, externas minutamente denticuladas; estames brancos, anteras 3-3,2 $\mathrm{mm}$ compr., uniporosas, conectivo eglanduloso, 0,3-0,4 $\mathrm{mm}$ prolongado abaixo das tecas, com projeção basal ampla, contínua da região ventral à dorsal, projetando-se ventralmente em dois apênices agudos; ovário 3-locular, glabro. Baga imatura verde-olivácea, madura enegrecida, ca. 30 sementes. (Fig. 2. I).

\section{Pirani et al. CFCR 13513 (SPF, UEC, US).}

Desde Mato Grosso e Pará até São Paulo. Em Grão-Mogol ocorre no cerrado em solo pedregoso. Floresce e frutifica em setembro.

\subsection{Miconia herpetica DC., Prodr. 3: 181. 1828.}

Arbustos 1,6 m alt. Ramos não alados, juntamente com pecíolos, face abaxial das folhas e hipanto com tricomas estrelado-estipitados e/ou dendríticos, amarelados, densos mas caducos no hipanto. Pecíolo 1-1,4 cm compr.; lâmina 5,69,5 cm compr., 2,8-4,8 cm larg., oval a elíptica, base arredondada a subcordada, ápice agudo ou acuminado, margem inteira e revoluta, nervuras 5 ou $3+2$, basais a curtamente suprabasais (1-2 $\mathrm{mm}$ acima da base). Panículas escorpióides, 4,6-7 cm compr., 3-4,8 cm larg. Flores 5-meras; hipanto ca. $2 \mathrm{~mm}$ compr.; cálice persistente, duplo, lacínias internas largamente triangulares, externas minutamente denticuladas; estames brancos, anteras ca. $2 \mathrm{~mm}$ compr., uniporosas, conectivo eglanduloso, ca. $0,2 \mathrm{~mm}$ prolongado abaixo das tecas, com cálcar dorsal alargado e com 2 aurículas ventrais; ovário 3-4-locular, glabro. Baga imatura verde, madura não vista, 7-10 sementes. (Fig. 2. J-K).

Campos et al. CFCR 13370 (SPF, UEC), Martius s.n. (M, síntipo).

Material adicional: Bahia, Fonseca et al. 472 (US). Minas Gerais, Glaziou 13836 (K, US).

Bahia e Minas Gerais (e talvez Goiás e Mato Grosso, como M. nambyquarae - ver comentários abaixo). Em GrãoMogol ocorre em cerrado denso. Frutifica em setembro. A coleta de Martius foi assinalada como proveniente de "Serra de Grão-Mogor et sylvis ... Lagoa Suja". Miconia nambyquarae Hoehne, de Mato Grosso e Goiás, supostamente difere de $M$. herpetica pelas folhas mais longas, lanceoladas (Goldenberg 432 - UEC, UPCB, US).

10.7. Miconia hirtella Cogn. in Mart., Fl. bras. 14(4): 419. 1888.

Arbustos 1,5-2 m alt. Ramos não alados e glabros assim como pecíolos, folhas e hipanto glabros, à exceção da face inferior na região próxima às nervuras com tricomas simples, canescentes, esparsos. Pecíolo 0,7-1,5 cm compr.; lâmina 4,1-11,2 cm compr., 1,2-3,2 cm larg., elíptica a oblonga ou elíptico-lanceolada, base aguda a estreitamente arredondada, ápice acuminado a cuspidado, margem serrado-ciliada, nervuras $3+2$, suprabasais $(2-5 \mathrm{~mm}$ acima da base). Panículas 6,4-1,3 cm compr., 3,5-6 cm larg. Flores 5-meras; hipanto ca. $1 \mathrm{~mm}$ compr.; cálice persistente, duplo, lacínias internas arredondadas ou triangulares, externas denticuladas; estames brancos, anteras 0,5-0,7 mm compr., quadriporosas, conectivo eglanduloso, prolongado $0,1-0,2 \mathrm{~mm}$ abaixo das tecas, com um cálcar curto, dorsal; ovário 3-locular, ápice glabro. Baga imatura verde ou azulada, madura enegrecida, ca. 30 sementes. (Fig. 2. L-N).

Giulietti et al. CFCR 9908 (SPF, UEC, US); Irwin et al. 23488 (K); Pirani et al. 12436 (SPF, UEC, US).

Goiás, Minas Gerais e Espírito Santo. Em Grão-Mogol ocorre em vegetação rala, à beira de riachos. Floresce e frutifica em julho e dezembro.

10.8. Miconia langsdorffii Cogn. in Mart., Fl. bras. 14 (4): 232. 1888 .

Arbustos ca. $1 \mathrm{~m}$ alt. Ramos não alados, juntamente com pecíolo, face abaxial das folhas, inflorescências e hipanto com tricomas estrelados, canescentes, esparsos, depois glabros. Pecíolo ca. 0,3 cm compr.; lâmina 3,6-7,7 cm compr., 0,6-1,4 cm larg., lanceolada, base obtusa a arredondada, ápice acuminado, margem serrilhada, nervuras 3 ou $3+2$ curtamente suprabasais (até ca. $2 \mathrm{~mm}$ acima da base). Panículas ou rácemos 2,6-4,4 cm compr., 1,4-2,2 cm larg. Flores 5-meras; hipanto 2,5-3 mm compr.; cálice caduco, duplo, lacínias internas não claramente definidas, externas longas, subuladas; estames amarelos, anteras 3-4 mm compr., uniporosas, conectivo basalmente glanduloso, $0,5 \mathrm{~mm}$ ou não prolongado abaixo das tecas, com 2 apêndices ventrais obtusos, às vezes com um terceiro apêndice dorsal; ovário 3-locular, glabro. Baga imatura avermelhada, madura enegrecida, 1025 sementes.

Hatschbach \& Guimarães 55029 (MBM).

Material adicional: São Paulo, Mogi-Guaçu, Ratter 4313 (MBM); Teodoro Sampaio, Pastore 200 (MBM). 
Desde Mato Grosso do Sul e Minas Gerais até o Paraguai e Paraná. Coletada apenas em Cristália, próximo a GrãoMogol, em "carrascal" (cerrado fechado). Frutifica em fevereiro.

10.9. Miconia ligustroides (DC.) Naudin, Ann. Sci. Nat. Bot., Ser. 3, 16: 167. 1850.

Arbustos ca. $1 \mathrm{~m}$ alt. Ramos não alados, juntamente com pecíolo e hipanto com tricomas estrelados, canescentes, esparsos e caducos. Pecíolo 0,1-3 cm compr.; lâmina 1,4-4 cm compr., 0,9-2,5 cm larg., elíptica a oval-elíptica, base arredondada a subcordada, ápice agudo a obtuso, margem inteira, nervuras 3 basais a curtamente suprabasais (ca. $1 \mathrm{~mm}$ acima da base). Panículas 4,1-6,3 cm compr., 3-3,6 cm larg. Flores 5-meras; hipanto ca. $1 \mathrm{~mm}$ compr.; cálice caduco, duplo, lacínias internas arredondadas, externas minutamente denticuladas; estames brancos, anteras 1,5-1,8 mm compr., uniporosas, conectivo eglanduloso, $0,2-0,3 \mathrm{~mm}$ prolongado abaixo das tecas, com um cálcar dorsal ou 3 apêndices (1 dorsal e 2 ventrais), todos diminutos; ovário 3-locular, glabro. Baga imatura verde, madura enegrecida, 20-30 sementes. (Fig. 2. O).

Hatschbach \& Ribas 55040 (MBM); Pirani et al. CFCR. 12640 (SPF, UEC).

Material adicional: Minas Gerais, Berilo, Hatschbach \& Silva 50198 (MBM).

Desde o Ceará até Santa Catarina. Em Grão-Mogol ocorre em cerrado aberto. Floresce em dezembro.

10.10. Miconia paradoxa (DC.) Triana, Trans. Linn. Soc. London 28: 121. 1871.

Arbustos 0,2-0,4 m alt. Ramos fortemente achatados e alados, glabros assim como pecíolos e folhas, inflorescências e hipanto com tricomas estrelados, castanhos, esparsos, caducos. Pecíolo 0,6-1,8 cm compr.; lâmina 5-9,4 cm compr., 2,2-4,8 cm larg., oval a elíptica, base cordada, ápice agudo a acuminado, margem inteira e hialina, nervuras $3+2$ ou 5, basais. Panículas, 5-12 cm compr., 2-3 cm larg. Flores 4-5-meras; hipanto ca. $3 \mathrm{~mm}$ compr.; cálice persistente, duplo, lacínias internas não claramente definidas, externas denticuladas; estames com anteras uniporosas, conectivo eglanduloso, inapendiculado; ovário 4-locular, ápice diminuta e esparsamente furfuráceo. Baga imatura verde, madura enegrecida, 25-50 sementes.

\section{Pirani et al. CFCR 10816 (SPF).}

Material adicional: Minas Gerais, Diamantina, Lombardi 4319 (UPCB); Souza 22163 (UPCB).

Endêmica de Minas Gerais. Em Grão-Mogol ocorre em locais sombreados, na beira de cursos de água. Coletada com frutos em fevereiro e março. $\mathrm{O}$ aspecto vegetativo das plantas desta espécie é bastante distinto, devido aos entrenós curtos, largos e alados, dispostos de forma decussada, e também por suas folhas coriáceas, com margens hialinas.

10.11. Miconia rimalis Naudin, Ann. Sci. Nat. Bot., Ser. 3, 16: 238-239. 1850.

Arbustos a arvoretas 1,5-3 m alt. Ramos não alados, juntamente com pecíolos, nervuras da face abaxial das folhas, superfície da face abaxial das folhas novas e hipanto com tricomas estrelados, ocráceos, esparsos, caducos. Pecíolo 0,81,3 cm compr.; lâmina 4,3-10,8 cm compr., 1,3-2,8 cm larg., lanceolada a elíptico-lanceolada, base cuneada e decurrente, ápice longamente acuminado a caudado, margem inteira ou repanda, nervuras 3 ou $3+2$, suprabasais $(5,1-8 \mathrm{~mm}$ acima da base). Panículas, 2,6-5,1 cm compr., 1,4-4,4 cm larg. Flores 5-meras; hipanto ca. $2 \mathrm{~mm}$ compr.; cálice caduco, duplo, lacínias internas triangulares, externas denticuladas; estames brancos, anteras ca. 1,6 mm compr., uniporosas, conectivo eglanduloso, prolongado ca. $0,2 \mathrm{~mm}$ abaixo das tecas, inapendiculado; ovário 3-locular, ápice papiloso. Baga imatura verde, madura enegrecida, 3-6 sementes. (Fig. 2. P-Q).

Cordeiro et al. CFCR 11550 (SPF, UPCB, US); Pirani et al. CFCR 12712 (SPF, UPCB).

Bahia, Minas Gerais e Espírito Santo. Em Grão-Mogol ocorre no interior da mata e cerrado denso. Floresce em novembro e frutifica em novembro e dezembro.

10.12. Miconia sclerophylla Triana, Trans. Linn. Soc. London 28: 119. 1871.

Arbustos a arvoretas 2-3 m alt. Ramos não alados, juntamente com pecíolos, nervuras da face abaxial das folhas e hipanto com tricomas dendríticos curtos, superfície da face abaxial com tricomas estrelados mesclados com tricomas estrelado-estipitados ou dendríticos longos, ambos amarelados a ocráceos, densos. Pecíolo 0,9-4,3 cm compr.; lâmina 4,313,3 cm compr., 2,2-4,9 cm larg., elíptica a elíptico-lanceolada, base arredondada a aguda, ápice agudo a obtuso, margem inteira, nervuras 3 ou $3+2$, curta ou nitidamente suprabasais (1-7 $\mathrm{mm}$ acima da base). Panículas de glomérulos, 11,9-13,9 cm compr., 4,5-7,9 cm larg. Flores 5-meras; hipanto 2,6-2,7 mm compr.; cálice caduco, duplo, truncado, com lacínias externas minutamente denticuladas; estames brancos, anteras 2,4-2,9 mm compr., uniporosas, conectivo eglanduloso, ca. $0,3 \mathrm{~mm}$ prolongado abaixo das tecas, com um cálcar dorsal estreito ou duas aurículas ventrais diminutas; ovário 2-locular, ápice glabro. Baga imatura verde, madura não vista, 1-2 sementes. (Fig. 2. R-S).

Hatschbach 42867 (MBM, US); Mello-Silva et al. CFCR 11443 (SPF, UPCB, US); Pirani et al. 4581 (SPF, UPCB); Silva et al. CFCR 12441 (SPF, UEC, US). 
Bahia e Minas Gerais. Em Grão-Mogol ocorre em matas ciliares e capões. Floresce em dezembro e frutifica em março.

O complexo formado por M. sclerophylla (tipo col. anônimo, s.d., K; ver Wurdack 1976) e M. maximowicziana Cogn. (tipo: Riedel 1205, K, P, citado como "Tejuca" - provavelmente Diamantina) e M. maximowicziana var. major Cogn. (tipo: Glaziou 17543, K, P, de "Minas Gerais") necessita reavaliação, visto que provavelmente trata-se de apenas uma espécie.

Outras duas espécies presentes em campos rupestres de Minas Gerais apresentam semelhanças em relação a $M$. sclerophylla: M.corallina Spring apresenta inflorescências com tricomas muito longos, conferindo às flores um aspecto "afundado" (ver Wurdack 1976) e M. chartacea Triana apresenta tricomas lepidotos na face inferior das folhas.

10.13. Miconia theaezans (Bonpl.) Cogn. in Mart., Fl. bras. 14(4): 419. 1888.
Arvoretas ca. $7 \mathrm{~m}$ alt. Ramos não alados, glabros assim como pecíolos, folhas e hipanto glabros. Pecíolo 0,6-1,3 cm compr.; lâmina 4,5-8,6 cm compr., 1,3-2,9 cm larg., elíptica a oblonga ou elíptico-lanceolada, base aguda a estreitamente arredondada, ápice acuminado a cuspidado, margem serreado-ciliada, nervuras 3 ou $3+2$, basais. Inflorescências e flores como em M. hirtella. (Fig. 2. T).

Pirani et al. CFCR 11438 (SPF, UPCB, US).

Do sul do México até Paraguai e Brasil (Santa Catarina), mas ausente na Amazônia. Em Grão-Mogol ocorre em mata ciliar. Coletada com botões em novembro. A distinção entre $M$. theaezans e M. hirtella é bastante discutível, e baseia-se na presença dos tricomas simples nas folhas e, às vezes, ramos de $M$. hirtella. É possível que se trate de apenas uma espécie, e a presença ou ausência destes tricomas mera variação morfológica.

\section{Microlicia D. Don}

Arbustos, subarbustos ou ervas, eretos, cespitosos ou não. Ramos pilosos, piloso-glandulosos ou glabros. Folhas sésseis ou subsésseis, geralmente não imbricadas, isomórficas, ovais, lanceoladas ou oblongo-lanceoladas, raro lineares, 1-3 pares de nervuras acródromas basais, frequentemente com pontuações glandulares. Flores 5-meras, isoladas ou agrupadas no ápice dos ramos, brácteas e bractéolas ausentes. Hipanto campanulado, subgloboso a urceolado, piloso ou glabro; lacínias triangulares a subuladas, persistentes; pétalas róseas, púrpuras, brancas ou amarelas; estames 10, dimorfos; filetes filiformes ou achatados; anteras ovóides a oblongas e curtamente rostradas; conectivos prolongados, com apêndices ventrais conspícuos nos estames ante-sépalos e inconspícuos nos antepétalos. Ovário 3-4(5)-locular, súpero, glabro. Cápsula loculicida, deiscente no ápice; sementes numerosas, oblongas ou reniformes, foveoladas.

1. Anteras tetrasporangiadas.

2. Folhas conduplicadas, densamente imbricadas, viscosas ....................................................................... M. tetrasticha

2'. Folhas planas, laxamente imbricadas, não viscosas ............................................................................ M. confertiflora

1 '. Anteras polisporangiadas.

3. Folhas linear-lanceoladas M. reichardtiana

3'. Folhas ovais a oval-lanceoladas.

4. Lacínias do cálice medindo metade do comprimento do hipanto M. fasciculata

4'. Lacínias do cálice medindo o mesmo comprimento que o hipanto, ou maiores

5. Hipanto geralmente com tricomas glandulares; lâmina foliar densamente hispida M. hispidula

5'. Hipanto com tricomas aglandulares; lâmina foliar glabra, raro esparsamente pilosa quando jovem M. insignis

11.1. Microlicia confertiflora Naudin, Ann. Sci. Nat. Bot., Ser. 3, 3: 176. 1845.

Subarbusto $0,5-1 \mathrm{~m}$ alt. Ramos com tricomas hirsutos não glandulares. Folhas sésseis; lâmina 6-8 mm compr., 5-6 mm larg., membranácea, oval, base obtusa a cordada, ápice obtuso, margem inteira ciliada, face abaxial pilosa, 3-5 nervuras. Flores isoladas, terminais, axilares, pedicelo $0,8 \mathrm{~mm}$ compr. Hipanto $3 \mathrm{~mm}$ compr, campanulado; lacínias $3 \mathrm{~mm}$ compr., 1 mm larg., subuladas. Pétalas 7-8 mm compr., $3 \mathrm{~mm}$ larg., liláses, oblongas, base atenuada, ápice agudo. Estames dimorfos, anteras tetrasporangiadas; estames antessépalos: filetes ca. $3 \mathrm{~mm}$ compr.; anteras $1 \mathrm{~mm}$ compr., oblongas; conectivo prolongado ca. $3 \mathrm{~mm}$ abaixo das tecas, bilobado; antepétalos: filetes ca. $2 \mathrm{~mm}$ compr., anteras $1 \mathrm{~mm}$ compr., oblongas; conectivo prolongado ca. $0,5 \mathrm{~mm}$. Ovário 3-locular. Cápsula 3-3,5 mm compr., ovóide; sementes ca. 0,3 mm compr., ovóides, foveoladas. (Fig. 3. A).

\section{Semir et al. 52 (UEC).}

Endêmica em Minas Gerais e aparentemente restrita à Serra do Espinhaço onde ocorre em campos rupestres, desde Ouro Preto até Diamantina e Grão-Mogol. Alguns indivíduos com flores e frutos são encontrados durante o ano todo. 


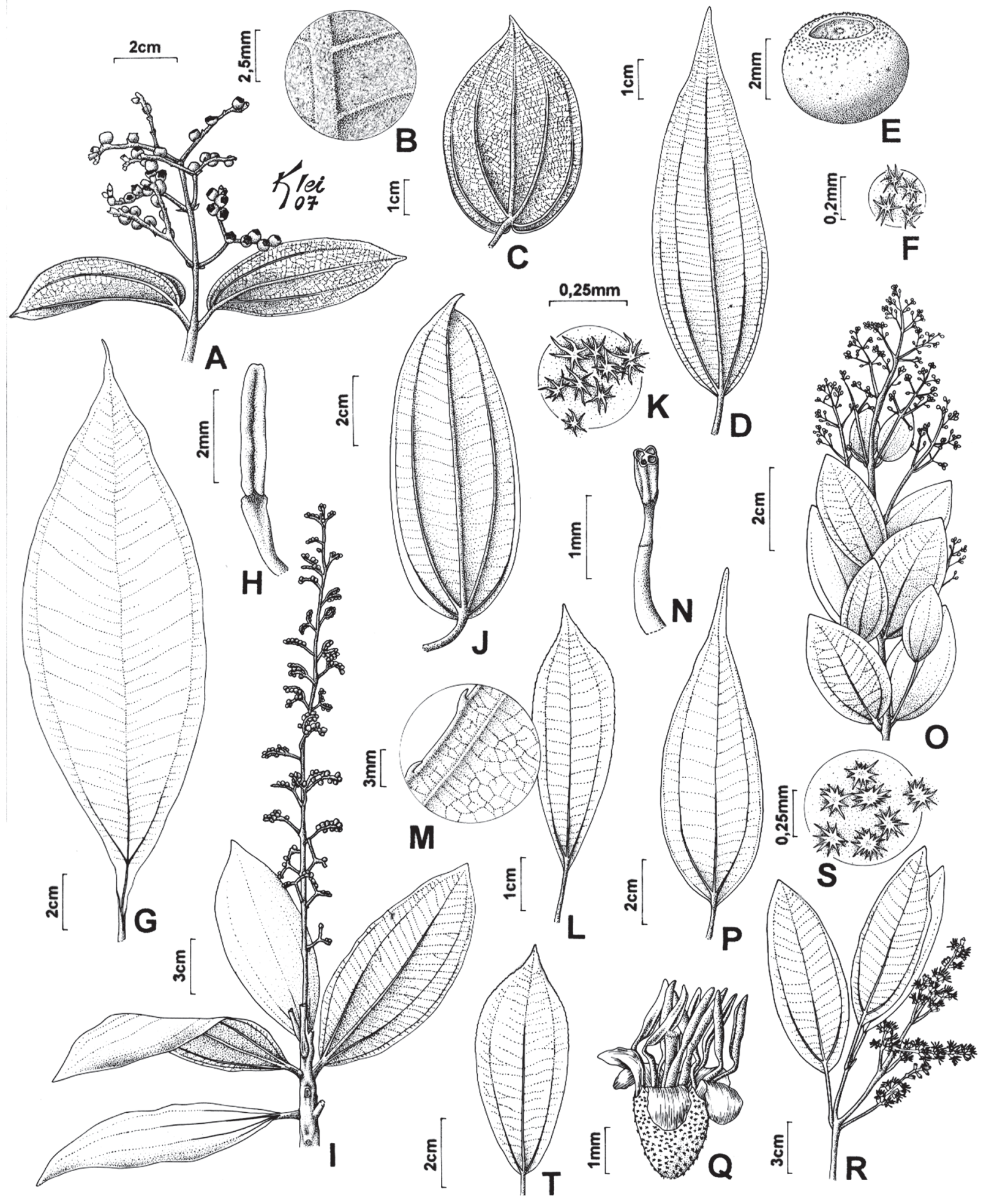

Fig.2. MELASTOMATACEAE. A-B. Miconia albicans: A. Ápice do ramo; panícula escorpióide; B. Face abaxial da folha (Mello-Silva \& Pirani CFCR 10859); C. Miconia alborufescens: face abaxial da folha (Zappi et al. CFCR 8424); D-F: Miconia cubatanensis: D. Face abaxial da folha; E. Ovário com tricomas estrelados; F. Detalhe (Pirani et al..CFCR 13019); G-H. Miconia elegans: G- Folha; H. Antera (Pirani \& Mello-Silva CFCR 10876); I. Miconia ferruginata: ápice do ramo com panícula escorpióide (Pirani et al. CFCR 13513); J-K. Miconia herpetica: J. Face abaxial da folha; K. Detalhe do indumento estrelado-dendrítico; L-N. Miconia hirtella: L. Face abaxial da folha; M. Margem serreado-ciliada; N. Antera quadriporosa (Pirani et al. 12436); O. Miconia ligustroides: ápice do ramo com inflorescência (Pirani et al. CFCR. 12640); P-Q. Miconia rimalis: P. Face abaxial da folha; Q. Flor (Cordeiro et al. CFCR 11550); R-S. Miconia sclerophylla: R. Ápice do ramo com panícula de glomérulos; S. Tricomas da face abaxial da folha (Mello-Silva et al. CFCR 11443); T. Miconia theazans: face abaxial da folha glabra (Pirani et al. CFCR 11438). 
11.2. Microlicia fasciculata Mart. ex. Naudin, Nov. Gen. et Spec. 3: 105. 1820.

Subarbusto $0,5-1 \mathrm{~m}$ alt, ereto. Ramos hirsutos com tricomas glandulares sésseis. Folhas sésseis; lâmina 2-8 mm compr., 2-4 mm larg., membranácea, oval a oval-elíptica, base arredondada, ápice acuminado, margem inteira ciliada, ambas as faces pilosas, 3 nervuras acródromas basais. Flores isoladas, terminais ou axilares, pedicelo $1 \mathrm{~mm}$ compr. Hipanto ca. $3 \mathrm{~mm}$ compr, urceolado, hirsuto e com glândulas sésseis; lacínias lanceoladas. Pétalas 7-8 mm compr., $3 \mathrm{~mm}$ larg., róseas, obovais. Estames dimorfos, anteras polisporangiadas; estames antessépalos: filetes ca. $3 \mathrm{~mm}$ compr.; anteras ca. 2 mm compr., oblongas; conectivo prolongado ca. $3 \mathrm{~mm}$ abaixo das tecas, apêndice $2 \mathrm{~mm}$ compr.; antepétalos: filetes ca. 2 $\mathrm{mm}$ compr., anteras ca. $1 \mathrm{~mm}$ compr., oblongas; conectivo prolongado ca. 1,5 mm, apêndice inconspícuo. Ovário ca. 2 mm compr., 3-locular. Cápsula 3,5 mm compr.; sementes ca. 0,3 mm compr., reniformes. (Fig. 3. B-D).

Bidá et al. CFCR 12007 (SPF, UEC); Cavalcanti et al. CFCR 8471 (SPF, UEC); Furlan et al. CFCR 718 (SPF); Giulietti et al. CFCR 9823 (SPF, UEC); Hatschbach 41222 (SPF, UEC, MBM); Pirani et al. CFCR 8394 (SPF, UEC); Zappi et al. CFCR 12894 (SPF, UEC).

Amplamente distribuída em Goiás, Distrito Federal, Mato Grosso do Sul, Bahia, Minas Gerais e São Paulo. Indivíduos desta espécie são encontrados preferencialmente em campos rupestres, cerrados, campos hidromórficos e adjacências. Para Cogniaux (1883), a espécie mais próxima seria M. polystemma Naudin, não encontrada em Grão-Mogol, que se distingue de $M$. fasciculata principalmente pelo hábito não cespitoso e anteras tetrasporangiadas. É também muito próxima de $M$. hispidula pelo tipo de indumento e pelas folhas sésseis e ovais. Esta espécie é algumas vezes identificada como $M$. graveolens, que apresenta tipicamente odor de terebintina liberado pelas folhas quando maceradas. Esse odor típico não pode ser percebido nas coletas de GrãoMogol. Floresce ao longo de todo o ano.

11.3. Microlicia hispidula Naudin Ann. Sci. Nat. Bot., Ser. 3, 3: 182.1845 .

Subarbusto 0,4-1m alt., densamente hirsuto-hispidulo nas porções superiores dos ramos. Folhas sésseis; lâmina 0,5-1 cm compr., 0,3-0,6 cm larg., cartácea, oval-lanceolada, atenuada na base e aguda no ápice, margem ciliada, ambas as faces hispidas, 5 nervuras acródromas basais. Flores isoladas no ápice dos ramos. Pedicelo $1 \mathrm{~mm}$ compr. Hipanto ca. $4 \mathrm{~mm}$ compr., campanulado, lacínias 4-5 mm compr. Pétalas 1-1,3cm compr., 0,6 -0,8 cm larg. Estames dimorfos, anteras polisporangiadas. Estames antessépalos com filetes $4 \mathrm{~mm}$ compr., anteras $2 \mathrm{~mm}$ compr., conectivo prolongado baixo das tecas $6 \mathrm{~mm}$, apêndice achatado $2 \mathrm{~mm}$; antepétalos com filetes $4 \mathrm{~mm}$ compr. e anteras 1,5 mm compr., conectivo prolongado baixo das tecas $2 \mathrm{~mm}$, apêndice tuberculado inconspícuo. Ovário 3-locular. Cápsula
5 mm compr., ovóidea. (Fig. 3. L-M).

Hatschbach 42884 (MBM, UEC); Mamede et al. CFCR 3403 (SPF, UEC); Mamede et al. CFCR 3468 (SPF, UEC); Pirani et al. CFCR (SPF, UEC); Sano et al. CFCR 12497 (SPF, UEC); Semir et al. CFCR 9633 (SPF, UEC).

Microlicia hispidula é muito semelhante a M. fasciculata. Ambas tem tricomas hirsutos, folhas ovais com margem ciliada. Entretanto, em M. hispidula as folhas são mais densamente imbricadas, o indumento também é mais denso, e as lacínias são do mesmo comprimento do hipanto, enquanto em M. fasciculata as lacínias são sempre menores que o hipanto.

\subsection{Microlicia insignis Chamisso, Linnaea 9: 388. 1834.}

Subarbusto $1 \mathrm{~m}$ alt., ereto. Ramos, ambas as faces das folhas e hipanto com longos tricomas hirsutos e glândulas sésseis, glabrescentes. Folhas subsésseis; lâmina 4-5 mm compr., 2-3 mm larg., membranácea, oval-lanceolada, base atenuada, ápice agudo, margem inteira, com longos tricomas aglandulares nas folhas mais jovens, ambas as faces com tricomas hirsutos esparsos ou glabras, 1 nervura acródroma basal. Flores isoladas ou agrupadas no ápice dos ramos, terminais ou axilares, pedicelo ca. $2 \mathrm{~mm}$ compr. Hipanto ca. $2 \mathrm{~mm}$ compr, campanulado; lacínias triangulares. Pétalas 8-9 mm compr., 3 mm larg., magenta, obovais. Estames dimorfos, anteras polisporangiadas; estames antessépalos: filetes $5 \mathrm{~mm}$ compr.; anteras ca. $2 \mathrm{~mm}$ compr., oblongas; conectivo prolongado ca. 5 mm abaixo das tecas, apêndice 1,5 mm compr., achatado; antepétalos: filetes ca $5 \mathrm{~mm}$, anteras ca. 1,5 mm compr., oblonga; conectivo prolongado ca. $2 \mathrm{~mm}$, apêndice ca. $0,8 \mathrm{~mm}$, achatado. Ovário $2 \mathrm{~mm}$ compr., 3-locular. Cápsula $4 \mathrm{~mm}$ compr.; sementes ca. 0,3 mm compr. (Fig. 3. E-F).

\section{Wanderley et al. 1426 (SP, UEC).}

Distribui-se em Goiás, Mato Grosso e Minas Gerais, onde ocorre em locais úmidos no cerrado.

11.5. Microlicia reichardtiana Cogn. in Mart., Fl. bras. 14(3): 60. 1883.

Subarbusto cespitoso 0,5 m alt., ereto. Ramos glabros ou com glândulas sésseis inconspícuas. Folhas subsésseis; lâmina 5-6 mm compr., $1 \mathrm{~mm}$ larg., coriácea, linear-oblonga a linear-lanceolada, base atenuada, ápice longamente apiculado, ambas as faces com pontuações glandulares, margem inteira, 1 par de nervuras acródromas basais. Flores isoladas ou agrupadas no ápice dos ramos, terminais ou axilares, pedicelo ca. $1 \mathrm{~mm}$ compr. Hipanto ca. $3 \mathrm{~mm}$ compr., urceolado, glabro ou com glândulas sésseis inconspícuas; lacínias lineares longamente apiculadas. Pétalas 8-9 mm compr., 4 mm larg., róseas, obovais. Estames dimorfos, anteras polisporangiadas; estames antessépalos: filetes ca. $2 \mathrm{~mm}$ compr.; anteras ca. 1,5 mm compr., oblongas; conectivo prolongado ca. $2 \mathrm{~mm}$ abaixo das 
tecas, apêndice $1 \mathrm{~mm}$ compr., achatado; antepétalos: filetes ca 2,5 mm compr., anteras ca. $1 \mathrm{~mm}$ compr., oblongas; conectivo prolongado ca. $1 \mathrm{~mm}$, apêndice inconspícuo. Ovário ca. $2 \mathrm{~mm}$ compr., 3-locular; cápsula ca. $4 \mathrm{~mm}$ compr., loculicida, globosa; sementes ca. 0,4 mm compr. (Fig. 3. G-H).

\section{Harley et al. 25064 (SPF, UEC).}

Cogniaux (1883), quando estabeleceu essa espécie, não mencionou a localidade onde havia sido encontrada em Minas Gerais, onde é aparentemente endêmica. Recentemente M. reichardtiana foi coletada também em Joaquim Felício, na Serra do Cabral, no campo rupestre, em solos arenosos, pedregosos, mesmo tipo de ambiente no qual foi encontrada em Grão-Mogol. Caracteriza-se por ser uma planta glabra de folhas lineares com tricoma longo no ápice, lacínias lineares bem maiores que o hipanto e anteras polisporangiadas.

11.6. Microlicia tetrasticha Cogn. in Mart., Fl. bras. 14 (3): 80. 1883.

Subarbusto $0,3 \mathrm{~m}$ alt., ereto, pouco ramificado. Ramos glabros. Folhas sésseis; lâmina $3 \mathrm{~mm}$ compr., $2 \mathrm{~mm}$ larg., coriácea, oval-lanceolada, base cordada, ápice acuminado, ambas as faces com pontuações glandulares, margem inteira, 1 nervura. Flores isoladas ou agrupadas no ápice dos ramos, terminais ou axilares, pedicelo ca. $1 \mathrm{~mm}$ compr. Hipanto ca. $3 \mathrm{~mm}$ compr, urceolado, com glândulas sésseis; lacínias lineares longamente apiculadas. Pétalas 6-8 mm compr., $4 \mathrm{~mm}$ larg., róseas, obovais. Estames dimorfos, anteras tetrasporangiadas; estames antessépalos: filetes ca. $2 \mathrm{~mm}$ compr.; anteras ca. $3 \mathrm{~mm}$ compr., oblongas, magenta; conectivo prolongado ca. $2,5 \mathrm{~mm}$ abaixo das tecas, apêndice $1,5 \mathrm{~mm}$ compr., achatado; antepétalos: filetes ca $2 \mathrm{~mm}$, anteras ca. 1,5 mm compr., oblongas, amarelas; conectivo prolongado ca. $1 \mathrm{~mm}$, apêndice ca. $0,5 \mathrm{~mm}$ compr, achatado. Ovário ca. $1 \mathrm{~mm}$ compr., 3-locular; cápsula ca. $2 \mathrm{~mm}$ compr., globosa; sementes ca. $0,2 \mathrm{~mm}$ compr. (Fig. 3. I-K).

$$
\text { Silva, et al. CFCR } 12471 \text { (SPF, UEC). }
$$

É semelhante a Microlicia insignis, que também ocorre em Grão-Mogol. Entretanto, as plantas de M. tetrasticha são viscosas e as anteras são tetrasporangiadas, enquanto Microlicia insignis apresenta anteras polisporangiadas Esta espécie cresce em locais de solo úmido arenoso em campos graminosos no campo rupestre. Coletada com flores e frutos em julho.

\section{Rhynchanthera DC.}

RENNER, S. S. 1990. A revision of Rhynchanthera (Melastomataceae). Nord. J. Bot. 9: 601-630.

Arbustos ou subarbustos, 0,3-2(3)m alt., ramos com tricomas glandulares. Folhas ampla ou estreitamente ovais a lanceoladas a lineares, sésseis, subsésseis ou pecioladas; margem geralmente serreada ou serrulada, 3-5(9) nervuras, ambas as faces com tricomas glandulares ou glabras. Inflorescência terminal e tirsóide. Brácteas semelhantes às folhas. Flores 5-meras, hipanto campanulado, lacínias linear subuladas a triangulares, pétalas obovais, róseas ou magenta, ocasionalmente brancas. Estames 5, antessépalos, geralmente um estame maior que os outros; estaminódios 5, antepétalos ; filetes glabros, anteras subuladas, rostradas, uniporosas; conectivo prolongado abaixo das teças; apendiculado. Ovário 3-5-locular, subgloboso,, súpero, apicalmente setoso ou glabro. Cápsula subglobosa ou campanulada, quase retas.

\subsection{Rhynchanthera grandiflora (Aubl.) DC., Prodr. 3: 107.} 1828.

Arbusto ou subarbusto, 05-1,2(-2)m alt., caule, pecíolos e inflorescências glandular-pubérulos ou glandular-tomentosos, Folhas subsésseis ou com pecíolo( 0,5$)-2,5-(3,7)$, lâmina geralmente ovada, (3-) 4,5-10cm compr, (2-)2,5-4,5cm larg, base cordada a atenuada, ápice agudo a acuminado, 3-4-nérveas, ambas as faces densamente pubescentes, margem ciliado-serrulada. Inflorescência tirsóide. Flores com pedicelos ca. $1 \mathrm{~mm}$, brácteas semelhantes às folhas principais, porém menores; hipanto ca. $5 \mathrm{~mm}$, glandular setuloso, lacínias linear-subuladas $6-15 \mathrm{~mm}$, com tricomas glandulares, pétalas magenta, obovadas $15-25 \mathrm{~mm}$. Estames do ciclo antessépalo dimorfos, com um bem maior que os outros, filete do estame maior ca. $8 \mathrm{~mm}$, do restante ca. $5 \mathrm{~mm}$, tecas $4-7 \mathrm{~mm}$, rostro ca. $4 \mathrm{~mm}$, conectivo ca. $10 \mathrm{~mm}$ no estame maior e ca. $5 \mathrm{~mm}$ nos menores, apêndice curtamente tuberculado. Ovário 3 (-4) 5-locular. (Fig. 2. N-O).
Mello-Silva et al. CFCR 9904 (SPF, UEC), Pirani et al. CFCR 8412 (SPF, UEC).

A espécie é provavelmente a mais comum e também a mais polimórfica do gênero, tanto em relação ao tipo de indumento quanto ao formato das folhas. Por este motivo, várias espécies anteriormente descritas foram a ela sinonimizadas (Renner 1990). Destaca-se das demais do gênero por apresentar um dos estames férteis bem maior do que os demais no ciclo ante-sépalo e folhas viscosas. Ocorre praticamente em todos os estados do Brasil e ao longo de todos os estados da América do Sul, além de México, Panamá, Colômbia, Guiana Francesa, Guiana, Suriname, Venezuela e Peru, com limite austral na Bolívia e Brasil central. É comumente encontrada em locais brejosos nas savanas e cerrados. Em Grão-Mogol foi encontrada em solo arenoso e entre rochas. Coletada com flores em julho e setembro. 


\section{Siphanthera Pohl.}

ROMERO, R. 1996. O genero Siphanthera Pohl ex DC. (Melastomataceae) no estado de Minas Gerais. Revta. bras. Bot. 20(2): 175-183.

Ervas ou subarbustos. Caule e ramos com indumento variável. Folhas sésseis ou subsésseis, membranáceas, margem inteira, serreada ou crenuladas, 1-5 nervuras. Flores isoladas, ou em panículas ou glomérulos. Flores 4-meras. Hipanto oblongo a campanulado, piloso-glanduloso; cálice com lacínias triangulares, persistentes. Pétalas lavanda, púrpuras ou brancas, obovadas ou arredondadas, discretamente unguiculadas. Estames 8, dimorfos; ante-sépalos férteis e antepétalos reduzidos a estaminódios; anteras ovóides a oblongas, rostradas; conectivo curtamente prolongado abaixo das tecas, apendiculado ventralmente. Ovário súpero, 2-locular. Cápsula subglobosa, deiscente no ápice. Sementes numerosas, ovóides e reniformes.

13.1. Siphanthera arenaria Cogn. in Mart., Fl. bras. 14(3): 193. 1885.

Erva $10-30 \mathrm{~cm}$ alt. Caule, ramos e hipanto piloso-glandulosos. Folhas sésseis; lâmina 1,5-7 mm compr., 0,8-3 mm larg., oval-oblonga, base arredondada ou cordada, ápice agudo, margem inteira, pilosa nas duas faces, 3-5 nervuras acródromas basais. Flores axilares ou terminais; pedicelo ca. $2 \mathrm{~mm}$ compr.; brácteas ca. $1,8 \mathrm{~mm}$ compr., $0,5 \mathrm{~mm}$ larg. Hipanto campanulado, ca. 1,5 mm compr.; lacínias persistentes ca. 1,5 mm compr., $1 \mathrm{~mm}$ larg. na base. Pétalas 2,5 $\mathrm{mm}$ compr., 2,3 mm larg., róseas ou purpúreas, obovadas. Estames antessépalos: filetes $1,5 \mathrm{~mm}$ compr.; anteras ca. 1 $\mathrm{mm}$ compr, ovóides; rostro ca. $0,3 \mathrm{~mm}$ compr.; conectivo prolongado $0,1 \mathrm{~mm}$ abaixo das tecas. Ovário 2-locular; cápsula $2 \mathrm{~mm}$ compr.,obovóide; sementes ca. $0,3 \mathrm{~mm}$ compr., ovóides. (Fig. 2. P-Q).
Barreto et al. CFCR 12051 (SPF, UEC); Bidá et al. CFCR 12005 (SPF, UEC); Cordeiro et al. CFCR 951 e CFCR 10090 (SPF, UEC); Giulietti et al. CFCR 9867 (SPF, UEC); Hensold et al. CFCR 3446 e 3454 (SPF, UEC); Simão-Bianchini et al. CFCR 12912 (SPF, UEC).

Romero (1997) comenta que essa espécie é encontrada somente em Minas Gerais. São plantas herbáceas, de no máximo $30 \mathrm{~cm}$ de altura, ocorrendo em campos arenosos e úmidos nos campos rupestres e áreas de domínio do cerrado. Caracteriza-se pelas flores tetrâmeras com 8 estames desiguais, sendo uma série fértil, de anteras com tubo apical longo (rostro), e outra estéril. Este tipo de antera oblonga terminando em tubo estreito, curto ou longo, caracteriza também os gêneros Lavoisiera, Microlicia, Rhynchanthera e Trembleya, cujas espécies estão presentes em Grão-Mogol, porém nesses gêneros as flores nunca são tetrâmeras. Em Grão-Mogol foi encontrada em solo arenoso. Floresce de abril a setembro.

\section{Tibouchina Aubl.}

GUIMARÃES, P.J.F. \& MARTINS, A.B. 1997. Tibouchina sect. Pleroma (D. Don) Cogn. (Melastomataceae) no estado de São Paulo. Revta. bras. Bot. 20(1): 11-33.

Arbustos, árvores ou raramente ervas. Ramos quadrangulares a subcilíndricos, algumas vezes alados, com indumento variado ou glabros. Folhas pecioladas ou sésseis, membranáceas a cartáceas, geralmente com tricomas nas duas faces, margem inteira, 1 a 4 pares de nervuras acródromas basais. Inflorescência em panícula terminal ou axilar, dicásios ou flores isoladas. Flores (4)5-meras. Hipanto campanulado ou tubuloso, seríceo, estrigoso ou glanduloso. Pétalas obovadas, roxas, magenta ou raramente róseas ou brancas, Estames (8)10, usualmente dimorfos; anteras geralmente linear-subuladas, ápice uniporoso; conectivo normalmente prolongado abaixo das tecas, em geral bituberculado, dorsalmente apendiculado. Ovário súpero ou parcialmente aderido ao hipanto, (4)5-locular com tricomas seríceos, raramente glandulares, no ápice. Fruto capsular. Sementes numerosas, cocleadas e tuberculadas.

1. Árvore ca. $6 \mathrm{~m}$ alt. T. candolleana

$1^{\prime}$. Arbustos 1 a $3 \mathrm{~m}$ alt.

2. Hipanto híspido; folhas estreitamente lanceoladas T. angustifolia

2'. Hipanto seríceo a setuloso; folhas ovais a oval-lanceoladas ou cordadas.

3. Panícula ca. $15 \mathrm{~cm}$ compr.; pétalas roxas com base branca T. heteromalla

3'. Panícula menor que $10 \mathrm{~cm}$ compr.; pétalas roxas.

4. Folhas coriáceas com $2,5-3,5 \mathrm{~cm}$ compr. e tricomas escabros T. glazioviana

4'. Folhas membranáceas com 4,5-7 cm compr. e tricomas velutino-glandulosos T. clidemioides 
14.1. Tibouchina angustifolia (Naudin) Cogn. var. lanceolata Cogn. in Mart., Fl. bras. 14 (3): 397. 1885.

Arbusto $3 \mathrm{~m}$ alt., densamente estrigoso. Pecíolo até $2 \mathrm{~mm}$ compr.; lâmina 3-4 cm compr, 6-8 mm larg., estreitamente lanceolada, base atenuada, ápice agudo, margem inteira, estrigosa, 3 nervuras. Flores solitárias ou aos pares no ápice dos ramos; pedicelo ca. $2 \mathrm{~mm}$ compr. Hipanto $4 \mathrm{~mm}$ compr., campanulado; lacínias $3 \mathrm{~mm}$ compr., triangulares. Pétalas 9-10 mm compr, $4 \mathrm{~mm}$ larg, roxas, obovadas. Estames dimorfos; filetes esparsamente piloso-glandulosos; antessépalos: filetes $5,5 \mathrm{~mm}$ compr., anteras $5 \mathrm{~mm}$ compr., subuladas, conectivo prolongado 1-1,5 $\mathrm{mm}$ abaixo das tecas; antepétalos: filetes $4 \mathrm{~mm}$ compr., anteras 3,5-4 $\mathrm{mm}$ compr., subuladas, conectivo prolongado 1-1,5 mm. Ovário 5-locular, 4 $\mathrm{mm}$ compr., ápice com tricomas setulosos; cápsula $6 \mathrm{~mm}$ compr. Sementes cocleadas. (Fig. 3. E-F).

Mello-Silva et al. CFCR 11489 (SPF, UEC).

A variedade em questão difere da variedade típica pelas folhas mais lanceoladas, que apresentam medidas maiores tanto no comprimento quanto na largura, quando comparadas a Tibouchina angustifolia var. angustifolia. $\mathrm{O}$ material examinado é constituído por apenas uma coleta, parecendo ser uma planta rara em Grão-Mogol, onde cresce à beira de riacho nas bordas de mata ciliar, e no estado de Minas Gerais. Outras coletas são necessárias para um melhor posicionamento taxonômico, aceitando-a realmente como uma variedade de $T$. angustifolia ou considerando-a uma nova espécie.

14.2. Tibouchina candolleana (DC.) Cogn. in Mart., Fl. bras. 14 (3): 339. 1885.

Arbusto $2 \mathrm{~m}$ de alt. Toda a planta recoberta por tricomas escabros. Pecíolo ca. $3 \mathrm{~mm}$ compr.; lâmina 6-8 cm compr., $2,5 \mathrm{~cm}$ larg., lanceolada, base atenuada, ápice agudo, margem inteira, ambas as faces escabras, 3 nervuras acródromas basais. Inflorescências paniculadas; flores com pedicelo ca. $3 \mathrm{~mm}$ compr. Hipanto $5 \mathrm{~mm}$ compr., campanulado, setuloso; lacínias $5 \mathrm{~mm}$ compr., oval-lanceoladas. Pétalas $3 \mathrm{~cm}$ compr, $1 \mathrm{~cm}$ larg, roxas, obovadas. Estames dimorfos; filetes densamente pilosos-glandulosos, ante-sépalos: filetes $10 \mathrm{~mm}$ compr., anteras $10 \mathrm{~mm}$ compr., subuladas, conectivo prolongado $1 \mathrm{~mm}$ abaixo das tecas, apêndice bituberculado, ca. $0,5 \mathrm{~mm}$ compr., piloso-glanduloso; antepétalos: filetes $10 \mathrm{~mm}$ compr., anteras $8 \mathrm{~mm}$ compr., subuladas, conectivo prolongado ca $1 \mathrm{~mm}$, apêndice bituberculado, piloso-glanduloso, ca. 0,3 $\mathrm{mm}$ compr. Ovário 5-locular, $4 \mathrm{~mm}$ compr., ápice setuloso; cápsula $7 \mathrm{~mm}$ compr. Sementes cocleadas. (Fig. 3. C).

\section{Pirani et al. CFCR 13400 (SPF).}

É uma espécie bastante comum nas matas ciliares. Ocorre nos estados da Bahia, Goiás, Minas Gerias e Distrito Federal (Guimarães 1992, 1997). Na Serra do Espinhaço, em várias localidades, indivíduos dessa espécie são facilmente observados na beira de rios e riachos, formando populações numerosas. Em Grão-Mogol ocorre em mata ciliar e foi coletada com flores em setembro.

14.3 Tibouchina aff. clidemioides (Berg.). Cogn. in Mart., Fl. bras. 14 (3): 398. 1885.

Subarbusto $1 \mathrm{~m}$ alt. Ramos com tricomas glandulares curtos; entrenós com longos tricomas. Folhas com pecíolo 1-2cm; lâmina 4,5-7 cm compr, 2,2-4 cm larg., membranácea, ovallanceolada, atenuada na base e aguda no ápice, ambas as faces velutino-glandulosas, margem inteira. Panículas. Flores 5-meras; pedicelo $4 \mathrm{~mm}$ compr. Hipanto ca. $5 \mathrm{~mm}$, oblongo, seríceo, com tricomas glandulares curtos; lacínias $3 \mathrm{~mm}$ compr, triangulares. Pétalas $10 \mathrm{~mm}$ compr, $9 \mathrm{~mm}$ larg., roxas com base branca, obovais. Estames dimorfos; antessépalos com filetes $6 \mathrm{~mm}$ compr, com diminutos tricomas piloso-glandulosos, anteras $8 \mathrm{~mm}$ compr., conectivo prolongado abaixo das tecas $1 \mathrm{~mm}$, apêndice tuberculado inconspícuos ca. $0,3 \mathrm{~mm}$; antepétalos com filetes $6 \mathrm{~mm}$ compr. com diminutos tricomas pilosoglandulosos, anteras $7 \mathrm{~mm}$ compr., conectivo prolongado abaixo das tecas $0,5 \mathrm{~mm}$, apêndice inconspícuo ca. $0,2 \mathrm{~mm}$. Ovário 5-locular, ca.3mm. (Fig. 4. G-H).

\section{Cordeiro et al. CFCR 975 (SPF, UEC).}

Espécie pouco conhecida, encontrada até o momento no Espírito Santo e Minas Gerais. Em Grão-Mogol, foi coletada com flores em abril, em margem de rio. Difere da descrição fornecida por Cogniaux (1885) no tamanho das folhas, que são menores no material de Grão-Mogol.

14.4. Tibouchina glazioviana Cogn. in Mart., Fl. bras. 14 (3): 325. 1885 .

Arbusto $2 \mathrm{~m}$ alt. Ramos estrigosos. Pecíolo ca. $4 \mathrm{~mm}$ compr., viloso; lâmina 2,5-3,5 cm compr, 1,3-2 mm larg., oval-lanceolada, base atenuada, ápice agudo, margem inteira, face abaxial vilosa, face adaxial escabra, 5 nervuras acródromas basais. Inflorescências paniculadas; flores com pedicelo ca. $3 \mathrm{~mm}$ compr. Hipanto $5 \mathrm{~mm}$ compr., campanulado, seríceo; lacínias $2 \mathrm{~mm}$ compr., triangulares. Pétalas 9-10 mm compr, 5-6 mm larg, roxas, obovadas. Estames dimorfos; filetes esparsamente pilosos-glandulosos, antessépalos: filetes $7 \mathrm{~mm}$ compr., anteras 6-7 mm compr., subuladas, conectivo prolongado $2 \mathrm{~mm}$ abaixo das tecas, apêndice bituberculado, ca. $0,5 \mathrm{~mm}$ compr.; antepétalos: filetes $2 \mathrm{~mm}$ compr., anteras $6 \mathrm{~mm}$ compr., subuladas, conectivo prolongado $1 \mathrm{~mm}$, apêndice bituberculado, ca. 0,3 $\mathrm{mm}$ compr. Ovário 5-locular, 4 $\mathrm{mm}$ compr., ápice densamente seríceo; cápsula $6 \mathrm{~mm}$ compr. Sementes cocleadas. (Fig. 3. D).

$$
\text { Cordeiro et al. CFCR } 10046 \text { (SPF, UEC). }
$$

Cogniaux (1885) descreveu para Tibouchina glazioviana folhas lanceoladas e atenuadas na base, o que entretanto não é observado na figura desta espécie. O material de Grão-Mogol apresenta folhas oval-lanceoladas a elípticas, com base arre- 


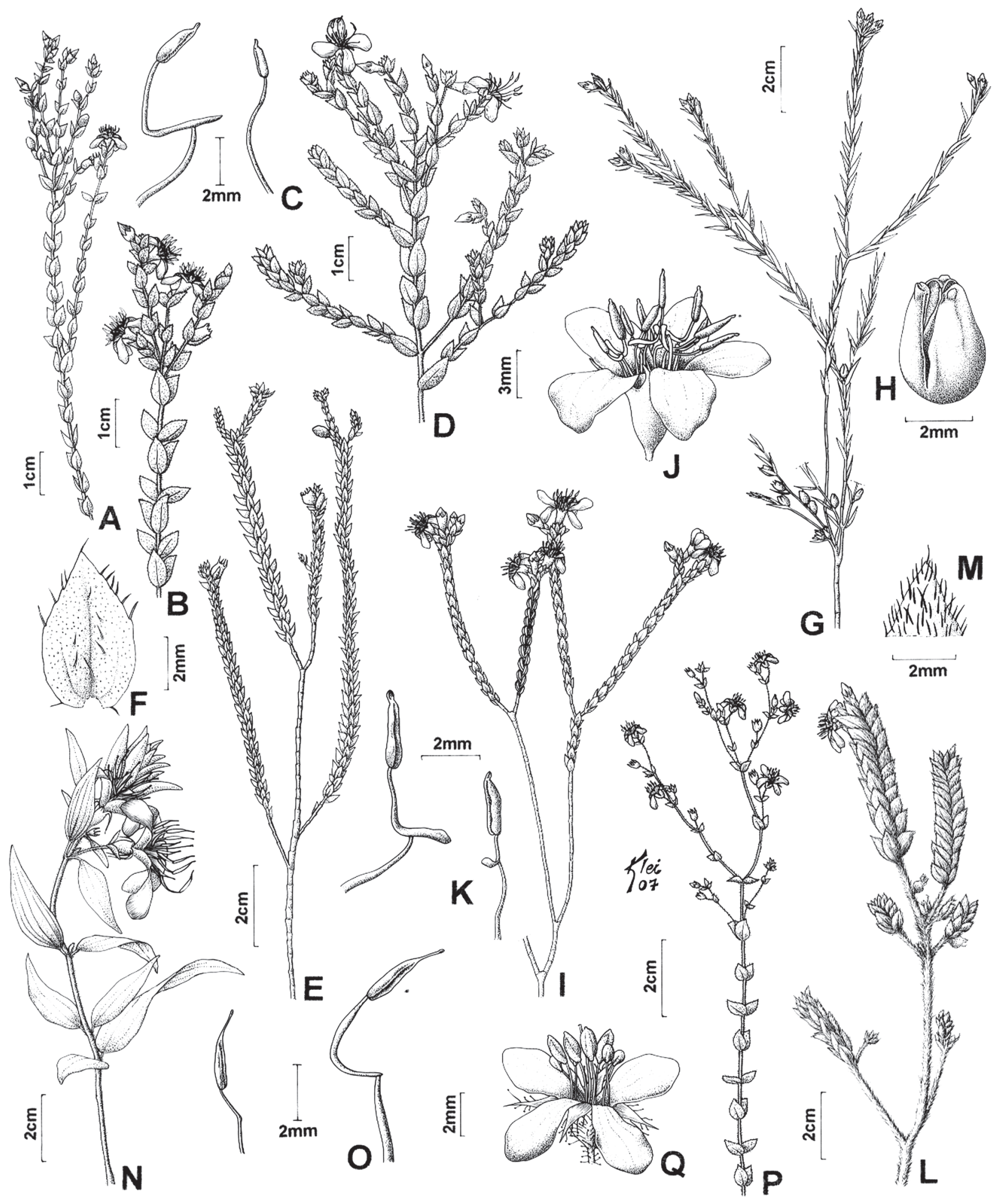

Fig. 3. MELASTOMATACEAE. A. Microlicia confertiflora: aspecto do ramo (Semir et al. 52 ); B-D. Microlicia fasciculata: B. Ápice do ramo; C. Estames dos dois ciclos (Cavalcanti et al. CFCR 8471); D. Aspecto do ramo (Furlan et al. CFCR 718); E-F. Microlicia insignis: E. Aspecto do ramo; F. Indumento da folha (Wanderley et al. 1426); G-H. Microlicia reichardtiana: G. Aspecto do ramo; H. Fruto com deiscência apical (Harley et al. 25064); I-K. Microlicia tetrasticha: I. Aspecto do ramo; J. Flor; K. Estames dos dois ciclos (Silva CFCR 12471); L-M. Microlicia hispidula: L. Aspecto do ramo; M. Indumento da folha (CFCR 3468); N-O. Rhynchanthera grandiflora: N. Ramo com inflorescência; O. Estames dos dois ciclos (Mello-Silva et al. CFCR 9904); P-Q. Siphanthera arenaria: P. Ápice do ramo; Q. Flor (Simão-Bianchini et al. CFCR 12912). 


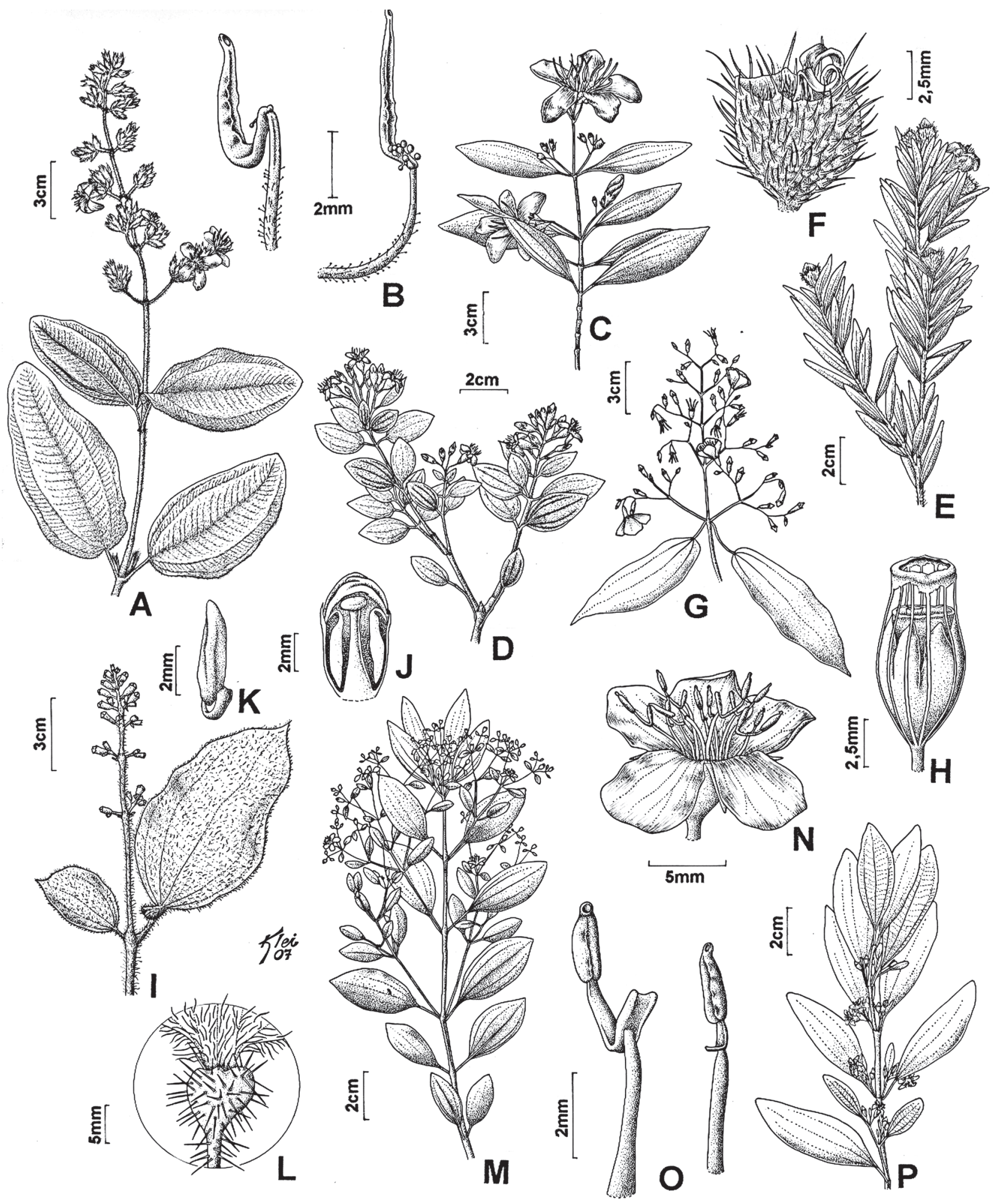

Fig. 4. MELASTOMATACEAE. A-B. Tibouchina heteromalla: A. Ápice do ramo com inflorescência; B. Estames (CFCR 12881); C. Tibouchina candolleana: Ápice do ramo (Pirani et al. CFCR 13400); D. Tibouchina glazioviana: aspecto do ramo (Cordeiro et al. CFCR 10046); E-F. Tibouchina angustifolia: aspecto do ramo; F. Fruto (Mello-Silva et al. CFCR 11489); G-H. Tibouchina aff. clidemioides: G. Aspecto do ramo; H. Fruto (Cordeiro et al. CFCR 975); I-L. Tococa guianensis: I. Ramo; J. Botão em corte longitudinal; K. Estame; L. Domácia (Pirani et al. 13492); M-O. Trembleya hatschbachii: M. Aspecto do ramo com inflorecências; N. Flor; O. Estames dos dois ciclos (Bidá et al. CFCR 11951); P. Trembleya parviflora: Aspecto do ramo com inflorescências (CFCR 9907) 
dondada, que diferem ligeiramente em relação à descrição mas estão de acordo com a ilustração existente na Flora Brasiliensis. Ainda nesta obra, a espécie é mencionada como coletada por Glaziou e proveniente do Rio de Janeiro. Este registro parece ser mais um engano decorrente de problemas na distribuição das exsicatas de Glaziou. Em Grão-Mogol foi coletada com flores em setembro, entre rochas, no campo rupestre.

14.5. Tibouchina heteromalla (D.Don) Cogn. in Mart., Fl. bras. 14 (3): 335.1885.

Arbusto até 1,7 m altura. Ramos quadrangulares estrigosos. Pecíolo 3-6,6 cm compr.; lâmina 12,5-21 cm compr, 8,5-15cm larg., oval-cordada a cordada, base cordada, ápice obtuso, raramente agudo, margem inteira, face adaxial estrigoso-serícea, bulada, face abaxial foveolada, vilosa, 5 nervuras. Inflorescência em panícula terminal; flores sésseis ou subsésseis. Hipanto 4-5 mm compr., tubuloso, seríceo; lacínias $3 \mathrm{~mm}$ compr., $2 \mathrm{~mm}$ larg., lanceoladas. Pétalas 1,3 cm compr, 1,2 cm larg., roxas, obovadas, base atenuada, ápice truncado. Estames dimorfos; filetes piloso-glandulosos, ante-pétalos: filetes $4 \mathrm{~mm}$ compr., anteras 3,5-4 mm compr., subuladas, conectivo prolongado 1-1,5 mm abaixo das tecas; ante-sépalos: filetes 5,5 mm compr., anteras $5 \mathrm{~mm}$ compr., subuladas, conectivo prolongado 1-1,5mm. Ovário 5-locular, $4 \mathrm{~mm}$ compr., ápice com tricomas seríceos. Cápsula 8 mm compr. Sementes cocleadas. (Fig. 3. A-B).

Furlan et al. CFCR 755 (SPF, UEC); Mamede et al. CFCR 3395 (SPF); Mello-Silva et al. CFCR 10045 (SPF, UEC); Menezes et al. CFCR 9699 (SPF, UEC); Pirani et al. 4575 (SPF, UEC).

Esta é uma das espécies mais polimórficas do gênero. Devido a isso, várias espécies foram estabelecidas por diversos autores e são hoje consideradas sinônimos (Guimarães 1997). Os exemplares de Grão-Mogol e outras localidades do Espinhaço, como Diamantina e Serra do Cipó, são frequentemente identificados como Tibouchina multiflora Cogn., que também consta da lista de sinônimos de T. heteromalla. A espécie é amplamente distribuída, ocorrendo desde o Ceará até São Paulo. Em Grão-Mogol foi encontrada em afloramentos rochosos e campos graminosos. Coletada com flores ao longo de praticamente todo o ano.

\section{Tococa Aubl.}

\section{MICHELANGELI, F. A. 2005. Tococa (Melastomataceae). Flora Neotropica Monographs 98: 1-114.}

Árvores ou arbustos procumbentes, raramente lianas. Ramos jovens e pecíolos glabros ou com tricomas. Folhas elípticas a lanceoladas, glabras a glandular-pubescentes, margens inteiras a ciliado-serruladas, raramente revolutas, ápice acuminado, aristado, agudo ou arredondado, base aguda a cordada, 3-7 nervuras acródromas basais ou suprabasais. Domácia frequentemente presente na base da lâmina foliar ou ápice do pecíolo. Inflorescência em panícula terminal ou racemo. Flores (4-)5(-6)-meras, hipanto raramente alado, glabro ou pubescente, cálice mais ou menos lobado, lacínias externas frequentemente desenvolvidas, deltóides ou subuladas, as internas raramente desenvolvidas. Pétalas obovadas a ovadas, normalmente brancas ou róseas, raramente vermelhas, verdes, amarelas ou laranja. Estames isomorfos ou subisomorfos; filetes raramente pubescentes na base, anteras geralmente eretas; conectivos frequentemente prolongados em um diminuto dente dorso-basal; ápice da teca acuminado com um poro apical. Ovário 1/3 a completamente ínfero, 3-(4-5) locular. Baga ovóide ou urceolada, azul ou preta quando madura. Sementes numerosas, truncado-obovadas, triangulares ou ovais.

\subsection{Tococa guianensis Aubl., Hist. Pl. Guiane 1: 438. 1775.}

Arbustos ou árvores, 1-5(7) m alt.; ramos glabros ou esparsamente indumentados. Folhas geralmente anisófilas, ovais a oblongo-elípticas, maiores 11-16 cm. compr, 8,5-10 cm larg., menores 5-8 cm compr., 4-5cm larg., ápice agudo a acuminado, caudado, base arredondada a aguda, ocasionalmente atenuada, face adaxial com tricomas adpressos, geralmente não glandulares, raramente glabra; face abaxial geralmente glandular setosa, 5-7 nervuras, membranáceas a cartáceas, margem serreado-ciliada, domácia livre, globóide a elipsóide. Inflorescência panícula terminal; hipanto amplamente cônico a globoso ca. $3 \mathrm{~mm}$ compr., glabro a densamente glandular setoso ou com uma mistura de tricomas lepidotos e e tricomas longamente glandulares, dentes do cálice externo deltóides ca. $1 \mathrm{~mm}$ compr.; cálice interno com dentes amplamente deltóides a ovóides, fundidos do meio até o ápice. Pétalas 5; amplamente oblongas a ovadas 3-5mm compr., 3-4mm larg., róseas. Estames isomorfos; filetes 2-3mm compr.; glabros, anteras amarelas, tecas $4 \mathrm{~mm}$ compr., abrindo por um poro ventral inclinado, ovário $2 \mathrm{~mm}$ compr., 3-locular, semi-ínfero, piloso no ápice. Frutos 10-20mm compr., globosos, pretos, glandular-setulosos, raramente glabros, sementes triangulares $0,6-12 \mathrm{~mm}$ compr. (Fig. 3. I-L).

Pirani et al. 13492 (SPF, UEC).

Amplamente distribuída do sul do México ao norte e leste da Bolívia, leste do Brasil e Guiana Francesa em florestas e savanas. Floração durante todo o ano. Pico de floração na estação chuvosa. Espécie mais variável e bem distribuída do gênero. Muitas espécies foram descritas com base na pubescência do ovário ou morfologia do cálice. Em Grão-Mogol foi coletada em orla de pequeno capão. 
MARTINS, E. 1995. Nova espécie do gênero Trembleya DC. (Microlicieae: Melastomataceae). Bol. Bot. Univ. São Paulo 14: $39-42$.

Árvores ou arbustos e subarbustos com tricomas glandulares, pedunculados ou sésseis. Folhas pecioladas ou sésseis, planas, frequentemente dimorfas ao longo do ramo; face abaxial da lâmina geralmente com nervuras salientes formando reticulações, em geral com tricomas glandulares de diversos tipos; margem integra, crenulada, denteada ou serreada. Inflorescências axilares, nos ápices dos ramos principais ou laterais; flores em dicásios simples ou compostos, ou reduzidos a apenas uma flor. Brácteas e bractéolas semelhantes às folhas, porém reduzidas. Flores 5-meras, sésseis a pediceladas. Hipanto campanulado a urceolado; lacínias triangulares, lineares ou oblongas, ou repandas inconspícuas, quase sempre persistentes; pétalas obovais, róseas, lilases ou púrpuras, brancas ou amarelas. Estames 10, dimorfos ou subisomorfos; anteras púrpuras no ciclo ante-sépalo e amarelas no ciclo antepétalo, ou brancas em ambos os ciclos, ovóide-oblongas ou linear-oblongas, curtamente rostradas, uniporosas, conectivos prolongados, com apêndices clavados, conspícuos nos estames ante-sépalos, e inconspícuos nos antepétalos. Ovário súpero, 3-5-locular. Cápsula loculicida, deiscente no ápice, hipanto persistente de mesmo comprimento ou prolongado e constricto acima do fruto. Sementes numerosas, ovóides, alongadas ou reniformes.

16.1. Trembleya hatschbachii Wurdack \& E.Martins, Bol. Bot. Univ. São Paulo 14: 39-42. 1995.

Arbusto 1,5-2 m alt., densamente vernicoso, sem tricomas ou estruturas glandulares individualizadas. Folhas com pecíolo 2-8 mm compr.; lâmina 5-7,5 cm compr., 2-3,5 cm larg., cartácea, concolor, elíptica, ápice agudo, base atenuada, 4 nervuras acródromas basais, sendo um par inframarginal, margem inteira. Inflorescências dicasiais axilares nos ápices dos ramos, brácteas 7-8 mm compr., 6-7 $\mathrm{mm}$ larg. Flores com pedicelos 2-3 mm compr., bractéolas 4-5 mm compr., 1-1,5 mm larg. Hipanto 3,5 mm compr., campanulado; lacínias ca. $3 \mathrm{~mm}$ compr., triangulares; pétalas 7-8 $\mathrm{mm}$ compr., 6-7 mm larg., amarelas, obovadas, ápice obtuso. Estames 10, dimorfos; antessépalos: filetes ca. $4 \mathrm{~mm}$ compr., conectivo prolongado ca. 2,5 $\mathrm{mm}$ abaixo das tecas, apêndice ca. $1 \mathrm{~mm}$ compr., bífido, antera ca. $2 \mathrm{~mm}$ compr., ovóideoblonga, púrpura, curtamente rostrada; antepétalos: filetes ca. $3 \mathrm{~mm}$ compr., conectivo prolongado ca. $1 \mathrm{~mm}$, apêndice curto bilobado, antera ca. $2 \mathrm{~mm}$ compr., ovóide-oblonga, rostro curto. Ovário ca. $3 \mathrm{~mm}$ compr. Cápsula ca. $3.5 \mathrm{~mm}$ compr., 5-locular. Sementes 0,2 mm compr., arredondadas. (Fig. 3. M-O).

Bidá et al. CFCR 11951 (SPF, UEC); Furlan et al. CFCR 771 (SPF, UEC); Hatschbach \& Ribas 52005 (MBM, holótipo; US, isótipo); Hatschbach 41337 (MBM, US); Hensold et al. CFCR 3525 (SPF, UEC); Leitão-Filho et al. 7893 (UEC); Oliveira et al. CFCR 12997 (SPF, UEC); Pirani \& Mello-Silva CFCR 10814 (SPF, UEC); Zappi et al. $C R C F 9906$ (SPF, UEC).

Espécie endêmica da Serra de Grão-Mogol na Cadeia do Espinhaço, onde foi coletada em campo rupestre ao longo de rio. Bastante distinta das demais espécies do gênero por suas flores amarelas e folhas elípticas, laxamente distribuídas ao longo dos ramos. Arbusto muito vernicoso, destituído de tricomas e estruturas glandulares individualizadas. Foi coletada com flores em abril, maio e setembro.
16.2 Trembleya parviflora (D.Don) Cogn. in Mart., Fl. bras. 14 (3): 128. 1883.

Arbusto a arvoreta com 2,5-4 m alt. Ramos jovens, pecíolos, hipanto, face abaxial da lâmina e pedúnculos com tricomas velutinos, eventualmente glandulares, curtos e longamente pedunculados, de densidade variável. Folhas com pecíolo 4-12 mm compr.; lâmina 2-11,5 cm compr., 0,3-4 cm larg., cartácea, lanceolada, ápice agudo a obtuso, base atenuada, discolor, face abaxial pruinosa, 2 nervuras acródromas basais, margem inteira. Inflorescências dicasiais axilares nos ápices dos ramos, brácteas 6-20 mm compr., 2-4 mm larg. Flores com pedicelos 1-4 mm compr., bractéolas 1- 7mm compr., 0,5-1,5 mm larg. Hipanto 2-3 mm compr., campanulado; lacínias $0,5-2,5 \mathrm{~mm}$ compr., triangulares, pétalas 5-11 mm compr., 2-7 mm larg., brancas, vináceas na base ou rosadas, obovadas, ápice agudo e acuminado. Estames 10, dimorfos; antessépalos: filetes 3,5 $\mathrm{mm}$ compr., conectivo prolongado ca. $3 \mathrm{~mm}$ abaixo das tecas, apêndice bituberculado $1 \mathrm{~mm}$ compr., antera ca. 1,5 mm compr., ovóide-oblonga, púrpura, rostro curto; antepétalos: filetes $2,5 \mathrm{~mm}$ compr., conectivo prolongado ca. $0,2 \mathrm{~mm}$, apêndice inconspícuo, antera $1,5 \mathrm{~mm}$ compr., ovóide-oblonga, amarela, rostro curto. Ovário $3 \mathrm{~mm}$ compr., 5-locular. Cápsula 3-6 mm de compr. Sementes 0,25 mm compr., alongadas. (Fig. 3. P).

\section{Cavalcanti et al. CFCR 8314 (SPF, UEC).}

Ocorre em cerrado, campo rupestre e bordas de matas ciliares desde a Bahia até o norte do Paraná, no estado de Minas Gerais, é amplamente distribuída ao longo da Serra do Espinhaço. Pode também ser encontrada em Mata Atlântica e campos de altitude, particularmente na Serra da Bocaina e Serra dos Órgãos. Em Grão-Mogol foi coletada a beira de riacho. Aparentemente floresce e frutifica ao longo de todo o ano. 